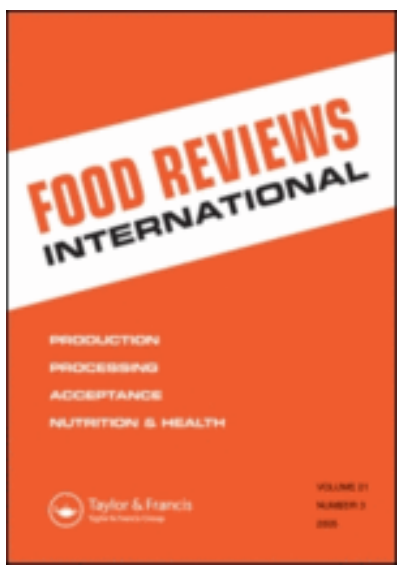

\title{
A global retrospective study on human cases of tetrodotoxin (TTX) poisoning after seafood consumption
}

\begin{tabular}{|r|l|}
\hline Journal: & Food Reviews International \\
\hline Manuscript ID & LFRI-2019-0012.R1 \\
\hline Manuscript Type: & Review \\
\hline Author: & n/a \\
\hline Complete List of Authors: & $\begin{array}{l}\text { Guardone, Lisa; Universita degli Studi di Pisa, Veterinary Sciences, } \\
\text { FishLab } \\
\text { Maneschi, Andrea; Universita degli Studi di Pisa, Veterinary Sciences } \\
\text { Meucci, Valentina; Universita degli Studi di Pisa, Veterinary Sceinces } \\
\text { Gasperetti, Laura; Istituto Zooprofilattico Sperimentale Lazio e Toscana } \\
\text { Nucera, Daniele; Universita degli Studi di Torino, Department of } \\
\text { Agriculture, Forest and Food Science } \\
\text { Armani, Andrea; Universita degli Studi di Pisa, Veterinary Sceinces }\end{array}$ \\
\hline Keywords: & Pufferfish, marine toxins, human poisoning, toxic fish species, risk \\
\hline &
\end{tabular}

\section{SCHOLARONE" Manuscripts}


$1 \quad$ Title:

2 A global retrospective study on Hhuman cases of tetrodotoxin (TTX)

3 poisoning intoxication-due to the ingestion-ofafter seafood products

4 containing tetrodotoxin: a global retrospective study consumption

5

6 Running head:

$7 \quad$ Human cases of TTX poisoning worldwide

8 Lisa Guardone ${ }^{\mathrm{a}}$, Andrea Maneschi ${ }^{\mathrm{a}}$, Valentina Meucci ${ }^{\mathrm{a}}$, Laura Gasperetti ${ }^{\mathrm{b}}$,

9 Daniele Nucera ${ }^{c}$, Andrea Armani ${ }^{a^{*}}$

10

11 a FishLab, Department of Veterinary Sciences, University of Pisa, Viale delle Piagge 2,

$12 \quad$ 56124, Pisa, Italy;

13 ' Istituto Zooprofilattico Sperimentale Lazio e Toscana, S.S. dell'Abetone e del Brennero 14 4, 56123 Pisa, Italy;

$15{ }^{c}$ Department of Agriculture, Forest and Food Science, University of Turin, Largo 16 Braccini 2, 10095, Grugliasco - Turin, Italy.

17

18

19 *corresponding author:

20 Postal address: FishLab, Department of Veterinary Sciences, University of Pisa, Viale

21 delle Piagge 2, 56124, Pisa (Italy)

22 Tel: +390502210207 ; Fax: +390502210213

23 Email: andrea.armani@unipi.it 


\begin{abstract}
25 Abstract
26 The presentA global retrospective study on human cases of tetrodotoxin (TTX)

27 intoxication caused by seafood consumption was eonductedaimed at updating the

28 relative risk according to seafood product categories and geographical areas. Overall,

293032 cases from five continents were collected, mainly from Asia. OverMore than half

30 of them-cases were attributed to fish, followed by gastropods, arthropods and

31 cephalopods. The intoxication source and its origin varied between geographical

32 regions: in South East and East Asia intoxications derived from all the aforesaid

33 seafood product categories, locally sourced; in Oceania, Sub-Saharan Africa and

34 Centre-South America from local pufferfish. In Europe dated cases were caused by

35 imported Asian products, as in North America. However, recent intoxications in Spain

36 and in Middle East and North Africa, caused by locally caught products, confirm the

37 occurrence of TTX even in areas previously marginally not affected by this public

38 health issue.
\end{abstract}

39

40 Keywords:

41 Pufferfish, marine toxins, human poisoning, toxic fish species, public health, 42 tetrodotoxin, risk 
44

45

46

47

48

49

50

51

52

53

54

55

56

57

58

59

60

61

62

63

64

65

66

67

68

\section{Introduction}

Tetrodotoxin (TTX) is one of the most potent neurotoxins known [1] and the most commonly involved in lethal marine poisoning [2]. In fact, TTX intoxication can $\underline{\text { be defined as a paralytic syndrome and it is part, together with ciguatera poisoning and }}$ Paralytic Shellfish Poisoning (PSP), of a group of major marine intoxications with neurological involvement [2]. TTX is a water-soluble heterocyclic guanidine that blocks $\underline{\mathrm{Na}+\text { conductance (Isbister and Kiernan 2005), inhibiting theits passage-of this ion into }}$ the membranes of excitable cells, such as muscle and nerve tissue, leading to $\underline{\text { immobilization [3]. Clinical signs develop rapidly, usually between } 10 \text { minutes and } 15}$ hours after ingestion of contaminated seafood products [4-6]. Early neurological symptoms include perioral and distal limb numbness and may be associated to nausea and vomiting. Severe poisoning causes generalized flaccid paralysis and cardiovascular effects. The severity of symptoms is dose-dependent, and death mainly occurs due to respiratory failure [1-2]. Since no specific antidote is available, therapy is mainly represented by aggressive supportive and symptomatic treatment [7].

Tetrodotoxin (TTX) is one of the most potent neurotoxins known (Hwang and Noguchi 2007) and the most commonly involved in lethal marine poisoning (Isbister and Kiernan 2005). The name TTX derives in fact from the Teleost fish order Tetrodontiformes (Nagashima \& Arakawa 2016Hanifin 2010), as the toxin has been isolated from members of this taxa, in particular from Tetraodontidae (pufferfish) [8-9]. In Japan pufferfish are considered a delicacy and TTX intoxication is an historically known issue [10]. In the past TTX was believed to be exclusively present in this taxonomic group (Noguchi and Arakawa 2008). However, TTX has been subsequently isolated also fromin other marine organisms such as tropical fish of the of the -Gobiidae family in Asian -[11], marine gastropods [12-15], bivalves [16-19], cephalopods (only 
Hapalochlaena spp., family: Octopodidae) [20], arthropods (only Carcinoscorpius rotundicauda and crabs of the Xanthidae family) [1,21], as well as Echinodermata (starfish, Astropectinidae), several taxa of worms (Turbellaria, Nemertinea, Anellida Polychaeta, Chaetognata) and algae [9]. Besides this wide range of marine species, TTX has also been isolated from a single class of terrestrial vertebrates (Amphibia: frogs and newts) [22]. Subsequently, an exogenous origin of TTX [9, 23] with marine bacteria as a primary source [17] has been hypothesized. Further discovers, such as TTX production by marine bacteria and the absence-of TTX toxicity in farmed pufferfish fed with non-toxic diets, together with the widespread occurrence of TTX in numerous phylogenetically unrelated taxa, allowed hypothesizing an exogenous origin (Magarlamov, Melnikova, and Chernyshev 2017; Noguchi and Arakawa 2008) with marine bacteria as a primary source (EFSA CONTAM Panel 2017). According to a recent literature review, 31 different bacteria genera able to produce TTX have been isolated until 2017, among which the most common is Vibrio spp. [23]. However, the pathway of TTX bioaccumulation in marine ecosystems is still subject to debate [2324].

TTX intoxication can be defined as a paralytic syndrome and it is part, together with ciguatera poisoning and Paralytic Shellfish Poisoning (PSP), of a group of major marine intoxications with neurological involvement (Isbister and Kiernan 2005). TTX is a water-soluble heterocyclic guanidine that blocks $\mathrm{Na}+$ conductance (Isbister and Kiernan 2005), inhibiting the passage of this ion into the membranes of excitable cells, such as muscle and nerve tissue, leading to immobilization (Denac, Mevissen, and Scholtysik 2000). Clinical signs develop rapidly, usually between 10 minutes and 15 hours after ingestion (Arakawa et al. 2010; Chew et al. 1983; Chowlhury et al. 2007). Early neurological symptoms include perioral and distal limb numbness and may be 
associated to nausea and vomiting. Severe poisoning causes generalized flaccid

paralysis and-cardiovascular effects. The severity of symptoms is dose-dependent, and

death mainly occurs due to respiratory failure (Hwang and Noguchi 2007; Isbister \&

Kiernan 2005). Since no specific antidote is available, therapy is mainly represented by

aggressive supportive and symptomatic treatment (Salzman, Madsen and Greenberg $2006)$.

based on puffer fish. Moreover, an official list concerning edibility of various species of

pufferfish and their tissues exists since 1983 [9] and is regularly updated [26]. Beside this country, restrictions are in place in China [27], Thailand [28], Taiwan [29], 109 Vietnam [30], in the USA [31] and in Europe [32]. 2011), Taiwan (Huang et al. 2014) and Vietnam (Cong and Tuan have banned or restricted the use of pufferfish. Limitation are in place also in the USA, where a single company is allowed to import Takifugu rubripes for restaurants. Moreover, consumption of local pufferfishes caught in coastal waters of the mid-Atlantic (between New York and Virginia state) is admitted since 114 these are considered free from the toxin, while the State of Florida currently has a ban en both commercial and recreational harvesting pufferfish

116 (https://www.fda.gov/food/recallsoutbreaksemergencies/safetyalertsadvisories/ucm0854 117 58.htm;

118 https://www.fda.gov/InternationalPrograms/Agreements/MemorandaofUnderstanding/u 
119

120

121

122

123

124

125

126

127

128

129

130

131

132

133

134

135

136

137

138

139

140

141

142

143

em107601.htm). Europe has a very stringent legistation as regards poisonous fish and

marine biotoxins. In fact, according to the Reg. (CE) n. 853/2004 "Fishery products

obtained from poisonous fish of the following families must not be placed on the

market: Tetraodontidae, Molidae, Diodontidae and Canthigasteridae".

T€The very wide range of organisms that can host TTX, the complexity of the

global seafood market, together with human intervention on the environment and climate change, has enhanced the risk of consumption of TTX-contaminated food also in countries not historically affected by this issue. Increasing worldwide trade of seafood products favors TTX intoxication due to fraudulent episodes [28, 33] or to illegal importation [34-35]. The arrival in 2003 of the toxic pufferfish Lagocephatus: sceleratus from the Red sea (Akyolet al. 2005), favored by

AAanthropogenic environmental modification and climate change have introduced TTX as an emerging public health problem in the Mediterranean area [3637]-due to the arrival in 2003 of the toxic pufferfish Lagocephalus sceleratus from the Red sea (Akyol et al. 2005). At least eleven species of the family Tetraodontidae have been reported in the Mediterranean Sea [38]. The arrival in 2003 of the toxic Lessepsian species L. sceleratus from the Red Sea aroused strong interest as it represents a potential public health hazard. In fact, several studies have confirmed the presence of TTX in this species [36, 39-42]. In addition, the toxin was also found in Lagocephaluslagocephalus [43] and recently in Torquigener flavimaculosus [44] and L. suezensis [42]. Similar factors are believed to be responsible of the spreading of TTX along the North East Atlantic Ocean coasts [45M. J. Silva et al. 2012].

The aim of the present work was to conduct a global retrospective study on human cases of intoxication due to the ingestion of seafood products containing TTX, considering that a-single outbreaks are often described in case reports and a similar comprehensive 
144 review on this topic is lacking. Therefore, In fact, Although other available reviews on

TTX intoxication exist (EFSA CONTAM Panel 2017; Hwang and Noguchi 2007; Lago

et al. 2015; Noguchi and Arakawa 2008; Panao et al. 2016), they deal with general

characteristics of the toxin and only report some intoxications-cases from different

geographical area. Besides, many single outbreaks are described in case reports and.

149 Since all these fragmentary data are fragmentary and had not been systematically

reviewed altogether., the aim of the present work was to conduct a global retrospective

study on human cases of intoxication due to the ingestion of seafood products

containing TTX. Specific attention was paid to the geographical area of the intoxication,

the source and its origin (local or imported). in order to better characterize the risk

154 factors mainly involved in human intoxication. from-by gathering fragmentary data on

155 TTX intoxication, outcomes from the present study could be useful to fulfil the actual

knowledge gap on the relative risk related to different food products and geographical

areas associated to this hazard, in order. This is particularly relevant in the light of

158 complex anthropogenic and environmental factors, including climate change, that could

159 modify the patterns of human intoxication. In fact, the complex anthropogenic and environmental scenario influences possible patterns of intoxication.

2. Materials and methods

\subsection{Literature search and selection of cases}

163 To review global cases of TTX intoxication in humans, literature data was searched on

164 PubMed and Google Scholar databases using the following keywords: (Tetrodotoxin OR TTX) AND (Poisoning) AND (Human OR Human case) AND (Europe OR America OR United States OR USA OR Africa OR Oceania OR Australia OR Asia).

167 The search was conducted using the terms altogether or differently combined in order to retrieve the maximum number of records. Cases described in Japan were excluded from 
169

170

171

172

173

174

175

176

177

178

179

180

181

182

183

184

185

186

187

188

189

190

191

192

193

the analysis, since the traditional consumption of pufferfish in this country makes the cases of intoxication very common and consequently not always reported in scientific articles in English. Thus, a literature search could be biased and give incomplete information on the real incidence of cases in this country. Furthermore, data on the incidence and prevalence of TTX intoxications in Japan are already available $[1,4,9$, 46]. An updated list of cases occurred between 2003 and 2017 is also reported - on the website of the Ministry of Health, Labour and Welfare of Japan [47]. The reference list of the screened articles was also checked for eligible new records and Google Scholar search option "cited by" was also used. Papers published in English, French, Italian, Spanish and Portuguese were included. Articles in other languages were also used if they presented an English abstract with sufficient details (see below). The search was concluded in April 2018. After deduplication, cases were considered eligible and included in the study when the following information was provided: i) number of intoxicated people; ii) geographical location/place of intoxication (at least at country level); iii) source of intoxication (at least the category of seafood responsible of intoxication). Cases included in the study were supported by clinical (including anamnesis and typical symptoms) and/or laboratory diagnosis.

\subsection{Data Extraction}

For each study, besides the minimal information (number of intoxicated people; geographical location/place of intoxication; source of intoxication) the following additional data were extracted, when available: date of intoxication, number of fatalities, age, sex, geographical origin of the source of intoxication and the part of the food source consumed (available only for fish products). All data were extracted using predefined fields in an Excel file. In order to process data from countries with similar geographical characteristics and bordering the same sea/ocean, the cases relating to 
194 America were subdivided into North America and Centre/South America, while data 195 from Asia and Africa were further subdivided and regrouped in the following sub-areas: South-east and East Asia, Middle East and North Africa and Sub-Saharan Africa. This division will be maintained in the subsequent analysis and discussion of the data. For the purposes of this work, products originating from the same geographical sub-area where the case of intoxication was reported from were considered locally sourced, as inclusion criteria. In the large majority of the cases, no laboratory analysis was carried

217 out to confirm the toxin involved and the TTX intoxication was clinically diagnosed on 218 the basis of the anamnesis and of the symptoms $(n=2641,87.1 \%)$. Only 375 cases were 
219

220

221

222

223

224

225

226

227

228

229

230

231

232

233

234

235

236

237

238

239

240

241

242

243

supported by a wide range of toxicological tests, often combined (detailed in Table 1SM). In addition, in 16 cases it was reported that the presence of TTX in the source was confirmed, but the test used was not specified.

Out of the 3032 cases, at least 341 were fatalities (11.2\%). Overall, precise age was available only for 304 cases of intoxications (10.0\%). In these cases, the intoxication showed the highest frequency in children under $10(23.3 \%)$, followed by thirties $(20.3 \%)$, forties $(18.0 \%)$, fifties $(11.5 \%)$, under 20 (11-20 years of age) $(10.5 \%)$, twenties $(9.5 \%)$, over sixty $(6.5 \%)$. In addition, in 169 cases the mean age was reported and in 517 cases an age range was indicated. The overall range was 4-74. As regards the sex ratio, gender was available for 1335 cases (44.0\%): 898 were males $(67.3 \%)$ and 437 were females $(32.7 \%)$.

\subsection{Geographical location}

Cases were reported from five continents (Fig. 1). The vast majority of the cases were described in Asia (Japan excluded, see section 2.1) ( $\mathrm{n}=2686,88.6 \%)$, followed by Africa $(n=203,6.7 \%)$, America $(n=90,3.0 \%)$, Oceania $(n=39,1.3 \%)$ and Europe $(\mathrm{n}=14,0.5 \%)$. As mentioned, data from America were subdivided into North America $(\mathrm{n}=23,0.8 \%)$, Centre/South America $(\mathrm{n}=67,2.2 \%)$, while data from Asia and Africa were further subdivided and regrouped as follows: South-East and East Asia ( $\mathrm{n}=2668$, 87.9\%), Middle East and North Africa $(n=168,5.5 \%)$ and Sub-Saharan Africa $(n=53$, 1.7\%). Complete details are given in Table 1. A significant difference in the fatality rate was observed in relation to the geographical area, both in terms of continents and in terms of sub-regions. As regards continents, Asia showed the lowest fatality rate (10.4\%), while the other 4 continents were comparable (15.4-21.4\%). As regards the sub-areas, Sub-Saharan Africa, Europe and North America showed statistically higher fatality rates $(20.8-30.4 \%)$ (Table 2$)$. 
244

245

246

247

248

249

250

251

252

253

254

255

256

257

258

259

260

261

262

263

264

265

266

267

268

\subsection{Source of intoxication}

The source of intoxication was represented by fish in 1817 cases $(59.9 \%)$, gastropods in 634 cases (20.9\%), arthropods in 492 (16.2\%) and cephalopods in 89 (2.9\%) (Fig. 2).

Data on the source of intoxication are detailed in Table 3 and briefly presented below. Among the fish category, most of the cases $(n=1703,93.7 \%)$ were due to the ingestion of fishes of the order Tetraodontiformes. Of these, 123940 were generically indicated as pufferfish. The remaining cases were due to the ingestion of species of different Tetraodontidae genera such as Takifugu, Lagocephalus, Arothron, Tetrodon, Sphoeroides, or to the ingestion of Diodon spp. $(\mathrm{n}=10)$ (Diodontidae - Porcupinefish) or of species of the Ostraciidae family $(\mathrm{n}=4)$ (Boxfish). The other fish species belonged to the family Gobiidae (Perciformes) $(n=33,1.8 \%)$ or were not identified $(n=82,4.5 \%)$ (Table 3). As regards gastropods, the large majority of intoxications $(n=618,97.5 \%)$ were attributed to the consumption of members of the order Neogastropoda, family Nassaridae and especially to species of the genus Nassarius spp. (n=468). A small number of cases was attributed to Natica fasciata, Charonia lampas, Oliva spp., Neverita didyma and to not identified gastropod species. Interestingly, intoxications due to the consumption of arthropods were exclusively due to Carcinoscorpius rotundicauda (horseshoe crab). Similarly, only one species, Hapalochlaena fasciata (blue-lined octopus), was involved in the cases related to the consumption of cephalopods $(\mathrm{n}=89)$ (Table 3$)$.

A significant difference in the fatality rate was observed in relation to categories of the sources involved. In fact, the fatality rate was significantly higher following the consumption of fish products $(16.3 \%)$ rather than other products categories (gastropods $4.9 \%$, arthropods $2.4 \%$ and cephalopods $2.2 \%$ ).

\subsubsection{Source of the intoxication in relation to the geographical sub-area}


269 The distribution of the different categories of product implicated in cases of 270 intoxications in relation to the sub-areas are summarized in Fig. 3 and described in 271 detail in Table 1 and Table 2SM. Only in South East and East Asia all the categories 272 were implicated: fish was responsible for around half of the intoxications $(n=1454$, $27354.5 \%)$, followed by gastropods $(n=633)$, arthropods $(n=492)$ and cephalopods $(n=89)$.

274 The only other sub-area where two categories were implicated was Europe (Table 1).

275 As regards South East and East Asia more in details, most intoxications caused by fish 276 were attributed to species belonging to the order Tetraodontiformes $(n=1354,93.1 \%)$.

277 Other fish species responsible for intoxications were gobiids, which do not belong to 278 this order and were reported as intoxication source exclusively from Asia, mainly from 279 China $(n=22)$ and to a lesser extent from Taiwan $(n=11)$. Of the 633 cases attributed to 280 gastropod consumption in Asia, the vast majority of them $(n=547,86.4 \%)$ occurred in 281 China, followed by Taiwan $(n=74,86.4 \%)$ and Vietnam $(n=547,86.4 \%)$.

C. rotundicauda intoxications $(\mathrm{n}=492)$ mostly occurred in Thailand $(\mathrm{n}=457)$, followed by Malaysia $(n=30)$ and China $(n=5)$. Intoxication cases caused by the consumption of a cephalopod retrieved in this study were found in Taiwan and Vietnam $(n=2$ and $n=87$ respectively).

In Middle-East and North Africa, except for 12 cases for which the fish species was not identified, the remaining 156 cases were generically attributed to pufferfish $(n=62)$ or specifically to Lagocephalus sceleratus ( $\mathrm{n}=94)$. This species was the only responsible 289 for intoxication in Israel $(n=16)$ and Lebanon $(n=2)$ and the responsible for most of the cases occurred in Egypt $(\mathrm{n}=76 / 147)$. Similarly, the limited number of TTX poisonings in Centre and South America $(n=67)$ were generically attributed to pufferfish $(n=47)$ or to a single pufferfish species, which in this subarea was Sphoeroides spp. $(\mathrm{n}=18)$. Also, the 53 cases reported in Sub-Saharan Africa, were exclusively caused by the 
294

295

296

297

298

299

300

301

302

303

304

305

306

307

308

309

310

311

312

313

314

315

316

317

318

consumption of pufferfish. They mainly occurred in the islands of the Western Indian Ocean, in particular on the Island of Reunion $(n=33)$, Madagascar $(n=17)$ and Zanzibar $(\mathrm{n}=1)$. As regards Oceania, TTX intoxications were mainly described in Australia $(n=31,79.5 \%)$ and exclusively caused by several species of fish belonging to the order Tetraodontiformes. In North America 23 TTX intoxications were reported, only from the United States and exclusively caused by pufferfish. The most implicated genera were Lagocephalus, in particular L. lunaris $(\mathrm{n}=4)$ and Arothron $(\mathrm{n}=4)$. Other identified species were Diodon hystrix $(\mathrm{n}=1)$ and Sphoeroides testudineus $(\mathrm{n}=1)$.

Finally, as regards Europe, the numerically scarce intoxications $(n=14)$ are for the most part fairly dated and caused by pufferfish $(n=13)$. The only remaining case occurred in October 2007 in Malaga, Spain, following the consumption of marine gastropods (Charonia lampas lampas) caught in the Southern coast of Portugal.

\subsubsection{Anatomical part of the seafood consumed}

The anatomical part consumed was indicated only for fish and in 287 cases of intoxication (16.8\%). Flesh was consumed in 121 cases $(42.2 \%)$, gonads in 73 cases (25.4\%) and liver in 33 cases (11.5\%) (Fig. 4). Different combinations of these body parts were ingested in the remaining 60 cases.

\subsubsection{Geographical origin of the source of intoxication}

Overall, data on the geographical origin of the food source was available for 1114 cases (36.7\%). The large majority were locally sourced $(n=1090,97.8 \%)$, while the remaining cases were imported $(n=24,2.2 \%)$. Differences related to the geographical areas were observed: in South East and East Asia, all the cases with known origin derived from locally sourced seafood products. Similarly, in Middle East and North Africa, the 27 cases with known origin were all due to local specimens, originating from the Mediterranean or the Red Sea. Also, in Centre-South America, Sub-Saharan Africa and 
319 Oceania all the cases with known origin were due to locally fished species. On the 320 contrary, in North America all the cases with known origin were related to fish imported 321 from Asia (China, South Korea, Japan). Finally, as regards Europe, 13 of the 14 322 reported cases were due to imported fish $(92.9 \%)$ while one case was due to the 323 consumption of local gastropod (Table 2SM).

\section{4. Discussion}

4.1. Cases of intoxications and diagnosis, fatality rate and toxicity of the seafood category

\subsubsection{Cases of intoxications and diagnosis}

identification of the species responsible for the intoxication, for example by the alimentary remains, can decisively direct the diagnosis [48-51]. The present results confirmed this trend, as in $87.1 \%$ of the cases, no laboratory analysis was performed (or underestimate the global occurrence of cases. However, toxin identification might be important to differentiate TTX intoxication compared to saxitoxin (STX) intoxication, both inducing similar symptoms. Moreover, both toxins can be isolated from the same 339 species, including pufferfish $[13,50]$. Te this end, the use of the mouse bioassay 340 (MBA), important to quantify toxicity, if used alone as it results-in 102 cases $(3.4 \%)$ included in the present work (Table 1SM), is not useful to discriminate the two toxins

342 [17]. For the identification of the specific toxin it is therefore important to apply 343 chemical-analytical or serological methods for analysing the fishery product, the food 
residue or the patient's blood or urine should be applied [2], as occurred in 273 cases

$(9 \%)($ Table $1 \mathrm{SM})$., for analysing the fishery product, the food residue or the patient's

blood or urine The research ofor TTX by HPLC allows its simple quantification of TTX

in urine and serum. However, while TTX ins serum TTX maybe is undetectable after

12 24h, TTXit can last up to 5 days in urine up to 5 days (Isbister and Kiernan 2005;

Oda et al. 1989; O'Leary, Schneider, and Isbister 2004).

\subsubsection{Fatality rate and toxicity of the seafood category}

351 utilization of different part of the fish as traditional food in some countries [52], might

367 be the explanation of the statistically significant differences observed for higher fatality rate. 

and Hapalochlaena spp. in the studies included in the analysis. However, the -a low toxicity of the horseshoe crab was evaluated in several works-showning low toxicity level in Thailand [53], Bangladesh and Cambodia [54-55]. Toxicological $Đ$ data on the toxicological profile of species of Hapalochlaena are described in searce. In a few 374 studies showingy the presence of the toxin in different organs was shown-[56-58]. Recently, the evolution and origin of TTX acquisition in the blue-ringed octopus has been reviewed [59].

\subsection{Geographical location, source of intoxication and its origin}

\subsubsection{South East and East Asia}

4.2.1.1. Source of intoxication. The fact that Mmost cases of TTX intoxications $(88.6 \%)$ occurred in Asia is not surprising and is in agreement with the literature data $[1-2,60$ -

61]. In fact, until 2005, TTX was mainly present in the warm waters of East and [65-66], Thailand [67] and Bangladesh [21, 68].

Fish products. The present study supports the fact that TTX intoxications caused 385 by pufferfish are still widespread in all Asia coastal countries-(M. S. Istam et al. 2011). 386 In Thailand, which was found as the country with the highest number of intoxication $\underline{s}$ 387 (29.5\% of the total intoxications in South-East and East Asia), pufferfish is in great 388 demand for its cheapness and its neutral taste-(Chulanetra et al. 2011). Pufferfish are 389 eaught and is frequently sold illegally, whole, in pieces and in the form of fish-balls, mixed with meat of other species, and they are available in specific restaurants called "Moo-Kata", which have become popular for this product. Their fraudulent sale-of 
people do not consume pufferfish as frequently as in Japan and there are large

restrictions in place, poisoning for consumption of wild specimens occurs fairly

frequently-(Arakawa et a1. 2010). Also iln Taiwan, poisoning cases are often due to

substitution of edible species with puffer roe or muscle -[1]. In Bangladesh, while the

coastal communities seem to be aware regarding the potential toxicity of pufferfish,

399 the 3 main outbreaks, involving 141 people in 2008, occurred in inland areas where the inhabitants, differently from coastal communities, ignored the potential toxicity of these species [69]. Poverty and food shortages-affecting a large part of the population of the country, together with a lack of control measures by the food safety authorities, increase the risk of poisoning, as pufferfish or their wastes not properly disposed of, are easily available in local markets at low cost $[60,69]$. The socio-economic context of $\underline{\text { Ppoverty }}$ and malnutrition may also partly explain the high mortality rate in this country, around $20.2 \%$, almost twice the Asian average (11.3\%). In Vietnam, especially in rural areas,

407 pufferfish are believed to be frequent responsible for intoxication since they are readily available and considered a delicacy, although their commercialization is actually-banned $409 \quad[30]$.

The intoxications due to Gobiidae were observed only in China and Taiwan, 411 likely due to the fact this seafood is usually consumed in Chinese coastal regions [70].

412 To date only 4 species of the Gobiidae family are known to be toxic due to the presence 413 of TTX and eurrently the sale or consumption of gobiids in China is not restricted. 414 Interestingly, several intoxicated patients declared that they were not aware of the 415 toxicity of these fish and that they had consumed them previously, without any 416 consequence [71].

Gastropod products. Most cases occurred in Taiwan and China, countries with a long tradition of consumption of small detritivorous gastropods, considered a delicacy 
419 in fishing villages and an economic nutritive food [72]. Marine gastropods are 420 historically involved in intoxications (Arakawa et al. 2010; Noguchi and Arakawa 421 2007)since they can effectively concentrate TTX if present in the marine environment 422 [10], even by the consumption of dead puffers [73]. Therefore, prevention must include 423 the prohibition of consumption of gastropods in Asian areas affected, unless coming 424 from certified marine areas (Shui et al. 2003).

425

426

427

428

429

430

431

432

433

434

435

436

437

439

440

441

442

Arthropod products. Cases of intoxications due to its consumption were only reported from Thailand, Malaysia and China. In fact, eggs of the horseshoe crab $C$. rotundicauda are frequently used to prepare traditional Thai dishes [74]. In Malaysia, horseshoe crabs' eggs or flesh are consumed mainly in coastal regions, where the inhabitants claim to know which parts of the animal need to be discarded to avoid adverse effects [75]. In addition, the misidentification of $C$. rotundicauda with a similar morphologically similar edible species, Tachypleyus gigas, enhances the intoxication risk [1]. The incorrect local beliefs that the toxin is inactivated by cooking, or that it is possible to distinguish between toxic and non-toxic C. rotundicauda specimens, are additional causes. C. rotundicauda is also consumed in Bangladesh, but studies on specimens caught in the local Bay of Bengal have shown a very low TTX content [55] and. In fact, no intoxications from this product were reported in this country.

Cephalopod products. Octopus of the genus Hapalochlaena spp. inhabit the shallow waters of Australia and Southeast Asia [20]. Hapalochlaena spp. octopus were found to be frequently responsible for TTX poisoning following inoculation through the bite, for example in Australia and Singapore [56, 76], while the intoxication as a result of food consumption is believed to be rare, as confirmed by the present study. 
4.2.1.2. Origin of the souree of intexication. All the South East and East Asian cases

with known origin derived from locally sourced seafood products. Even for cases not reporting this information the origin could be considered as local based on the distribution area of the species responsible for intoxication. This is not surprising 447 considering that in Asia the presence of TTX is an endemic problem [10]._In addition,

factors such as culinary traditions, poverty and weak control by the competent

authorities in some countries, as well as legistative deficiencies, favour the intoxication

eccurrence (How et al. 2003; M. S. Islam et al. 2011; Q. T. Islam et al 2011; Lewis

2017).

For this reasonreason, Consequently, several Asian countries issued a specific 453 legislation. In China a ban on trading and consuming products derived from pufferfish remained in force from 1990 to 2016, although breeding for export was allowed. At the end of 2016, this ban was removed and two farmed species (Takifugu rubripes and Takifugu obscurus) were reintroduced on the internal market

457 [27http://www.newschinamag.com/newschina/articleDetail.do?article id=910\&section458 id=26\&magazine id=]. Among the other Asian countries also Thailand [28], Taiwan 459 [29] and Vietnam [30] have banned or restricted the use of pufferfish.

\subsubsection{Middle East and North Africa}

461 Intoxication in this region were frequently attributed to L. sceleratus. Interestingly, the 462 intoxication cases caused by this species are quite recent (91 after 2005 and 3 in which 463 the date is not specified but reported by recent works). These data are related to the 464 recent invasion of the Mediterranean Sea by this species that reached the Eastern 465 Mediterranean in 2003 [77], following a Lessepsian migration through the Suez Canal 466 (Guardone et al. 2018). In addition to these cases, a serious case of intoxication by $L$. 467 sceleratus was registered in August 2013 in Tunisia, in the inland town of Gafsa [78]. 
468 Since no sufficient details were available for the intoxication (number of patients 469 involved), it was not included in the analysis. This incident occurred despite a nationat awareness campaign following the commercialization of $L$. sceleratus in the internal areas of the country, where people, as in Bangladesh (Islam et al. 2011b), were not aware of the risks posed by this species (Ben Souissi et al. 2014).Considering the high 473 toxicity and the widespread diffusion of L. sceleratus in the Mediterranean Sea [38], it 474 is reasonable to assume that this speciesit may also be involved in part of the remaining 47574 intoxications in this geographical area (of which at least 60 occurred after 2003), 476 although the source was identified only as "generic pufferfish", "unidentified fish" and 477 "Tetraodontidae".

478 Data arising from the analysis of the origin of the intoxication source which, when 479 available, was always local, support the role of $L$. sceleratus as an emerging problem of 480 food safety and public health in the Mediterranean [36-38]. This issue lead in fact to 481 various informative interventions and initiatives to prevent its consumption in the 482 countries bordering the Mediterranean basin (Andaloro et al. 2016; Ben Sourssi et al. $483 \quad$ 2014; Kalogirou 2013).

\section{4.2.3. Central-South America}

485 Although pufferfish is not a typical dish of Brazilian cuisine, and intoxications are rare 486 [50], in some regions of the north-east of the country it is consumed routinely [79]. The 487 involvement of the genus Sphoeroides is in agreement with its geographical distribution 488 and toxicity. In fact, it is one of the most common pufferfish genus in the waters facing 489 Brazil [80]. This widespread occurrence favours the local origin of the source of 490 intoxication. In Brazil, in fact, the intoxication by pufferfish mainly occurred as a family 491 event, often involving at the same time people from the same family or groups of 492 fishermen who consumed the fish they caught $[50,80]$. 


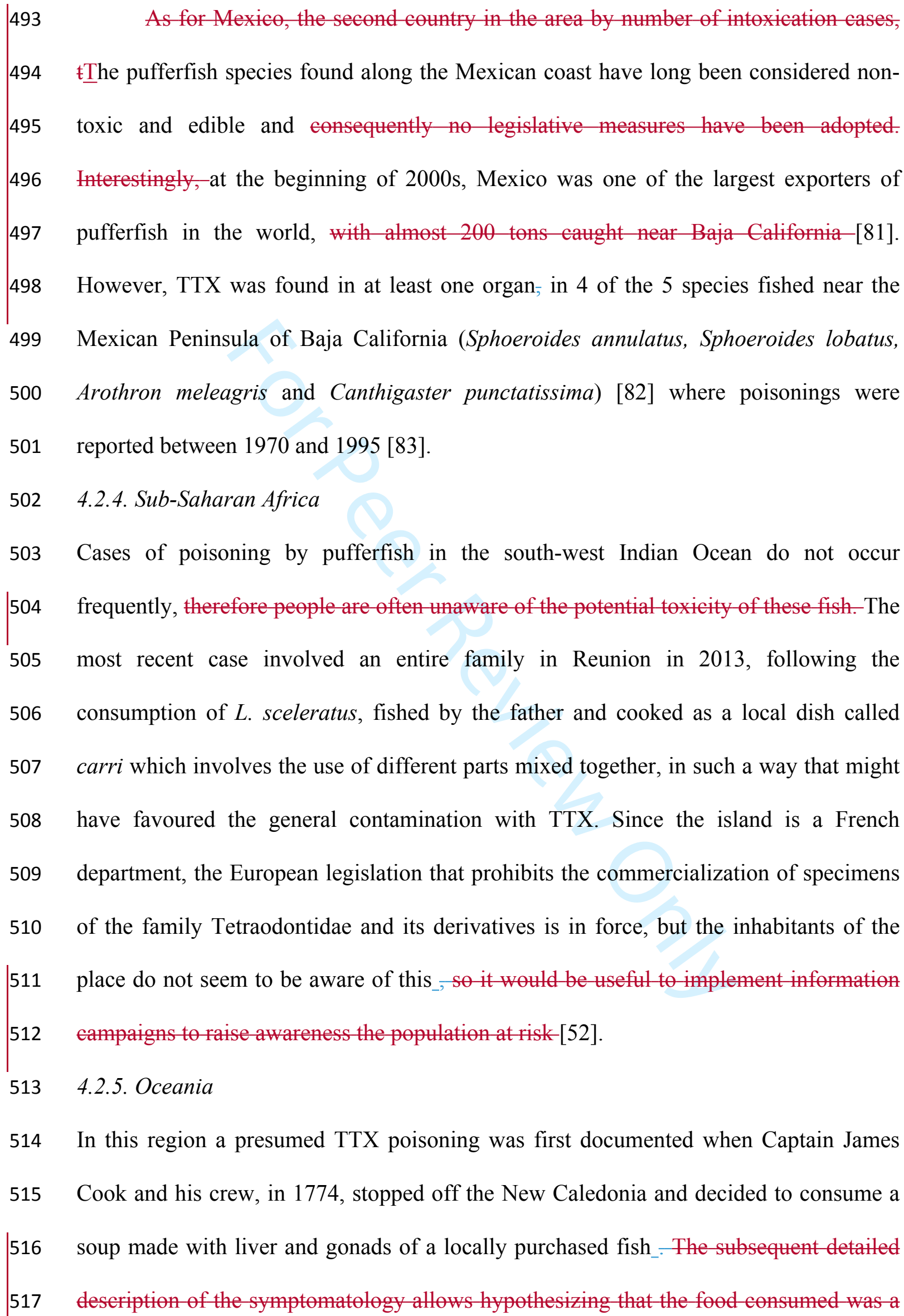


518 pufferfish-[84]. Although pufferfish intoxications in this area are described as rare, the 519 risk of TTX poisoning exists given the presence of several species of pufferfish in many 520 Australian coastal regions [2]. In fact, an interesting biodiversity was observed in the 521 source of intoxication in Oceania:- In particular, other than Tetraodontidae also 522 Ostraciidae and Diodontidae (among which Diodon hystrix) were reported as 523 responsible for human cases. Even though boxfish (family Ostraciidae) and 524 porcupinefish (family Diodontidae) are considered as "non-toxic species" [85] in a 525 study by Elshaer [86] TTX has beenwas extracted from ovary and muscle of $D$. hystrix. 526 Therefore, the toxicity of these species of Tetraodontiformes needs to be further 527 clarified.

528 Similarly, to Central-South America, the origin of the source of intoxication was 529 always local and in most of the cases it involved products caught during recreational 530 fishing sessions and consumed together-with the family (Table 2SM)-(Maillaud et al. 2016; Tibbals 1988; Torda, Sinclair, and Ulyatt 1973; Trevett, Mavo, and Warrell 532 1997).

\section{4.2.6. North America}

534 In North America TTX intoxications were exclusively caused by pufferfish. The most 535 implicated genera were Lagocephalus, in particular L. lunaris, involved in cases after 536 1996, and Arothron, responsible for very dated cases occurred in Hawaii between 1903 537 and 1925 [1]. In addition, for 3 out of 13 cases generically attributed to pufferfish it is 538 possible to hypothesize that the species involved was L. lunaris [33]. As in Oceania, a 539 case of intoxication was related to the consumption of D. hystrix [87].

540 The 12 oldest intoxication occurred between 1903 and 1986 in Hawaii and in Florida, 541 which caused at least 7 deaths, are unfortunately poorly detailed. More details are 542 available for the 11 more recent poisonings, $\bar{s}_{-}$- between-(1996-_and-2014). All were 
543 caused by products imported from Asia. In 1996 in California 3 cooks were intoxicated

544 by a ready-to-eat product made of fugu bought in Japan and illegally brought to the 545 USA ([34].

Subsequently, 7 cases occurred between 2006 and 2007 were traced back to a

547 Californian wholesaler who supplied local vendors and restaurants in different countries

548 with products labelled as gutted and beheaded monkfish of Chinese origin. In 4 of these, 549 substitution with L. lunaris (whose muscle contains TTX) was confirmed by molecular 550 identification and, probably, this species was involved in all 7 cases [33]. Finally, in 5512014 a pufferfish intoxication occurred in Virginia, in a person who had received a 552 parcel from relatives in South Korea, [35https://www.foodsafetynews.com/2014/01/fda553 investigating puffer fish-poisoning in-virginia/\#.W1WZ5NIzbIX]. This framework 554 shows that the risk of TTX intoxication in the USA comes mainly from imported 555 products, despite the stringent legislation in force. In fact, a single company is allowed 556 to import Takifugu rubripes for restaurants. Moreover, as regards eonsumption of-local 557 pufferfishes, consumption of those caught in coastal waters of the mid-Atlantic 558 (between New York and Virginia state) is admitted since these are considered free from 559 the toxin, while the State of Florida currently has a ban on both commercial and 560 recreational harvesting of pufferfish [31]. The ban was established after the largest 561 outbreak due to pufferfish intoxication in the US history [88], which however was 562 caused by saxitoxinSTX and not by TTX (these cases were not included in our 563 analysis). On the contrary, endemic pufferfish represented an important source of protein and income for the East Coast populations of the USA during the Second World War and in the following decales (Sibunka and Pacheco 1981). Despite the TTX poisonings 
568 pufferfish of the United States were considered as safe for a long time (Quilliam et at. 569 2002). However, between 2002 and 2004, 28 pufferfish poisonings occurred and were attributed to specimens caught in Florida (Bodager 2002; Landsberg et al. 2006), 571 representing the largest outbreak due to pufferfish intoxication in the US history (Deeds 572 et al. 2008). The responsible toxin was identified as saxitoxin and not TTX, therefore 573 these cases were not included in our analysis. Prior to 2002, no toxicity from pufferfish 574 originating from the region had ever been reported and the same 7 cases reported above in Florida had been caused by specimens caught outside this specific area (Deeds et at.

576 2008). Following this event, the FDA imposed a ban on the capture and consumption of 577 local pufferfish in force only for certain counties on the east coast of the State of 578 Florida, while the specimens fished in the Middle Atlantic remain fishable and tradable as non-toxic between the states of Virginia and New York (FDA,

2014https://www.fela.gov/food/recallsoutbreaksemergencies/safetyalertsadvisories/ucm

$581 \quad$ 085458.htm). However, a risk of TTX intoxication due to the presence of highly toxic 582 Sphoeroides species is potentially present in the area Deeds et al. (2008).4.2.7. Europe

583 All the 13 dated cases occurred in Europe were always due to the ingestion of imported mislabelled pufferfish. In addition, intoxications occurred in France due to mislabelling of fillets of pufferfish sold as burbot (Lota lota) (de Haro et al. 2008) and a mass hospitalization of the crewmembers of a tanker off Crete Island was reported, following

587 the consumption of $L$. sceleratus. However, since it was not possible to obtain sufficient 588 data (number of patients involved) on these cases, they were not included in the analysis.

590 As mentioned, tThe 13 dated poisonings caused by pufferfish, are all related to the 591 consumption of Asian-Taiwan imported frozen pufferfish, fraudulently labelled as 592 anglerfish, food-and all occurred Italy (Table 2SM) $\div 7$ in Iesolo and 3 in Rome in 1977 
(Pocchiari 1977) and 3 in Pavia in the following year (Viviani et al. 1978). The

responsible product was frozen pufferfish, imported from Taiwan and fraudulently

tabelled as anglerfish (Pocchiari 1978), similarly to the intoxication occurred in France

(de Haro et al. 2008). In addition, a similar intoxication occurred in France due to mislabelling of fillets of pufferfish sold as burbot (Lota lota) [89] and a mass

hospitalization of the crewmembers of a tanker off Crete Island was reported, following

the consumption of $L$. sceleratus. However, since it was not possible to obtain sufficient

data (number of patients involved) on these cases, they were not included in the analysis.

Interestingly, Tthe remaining recent European case of European-intoxication due the consumption of a marine gastropod caught in Portugal $[13,90]$ is, on the contrary, confirmed by the study of M. J. Silva et al. [15] on gastropods from North Portugal.

609 Subsequently, TTX was found in bivalves (Mytilus edulis and Crassostrea gigas) 610 collected in the English Channel between February 2013 and October 2014 [18, 91] and 611 in oysters and mussels collected from different Dutch production areas in 2015 and 6122016 [17]. Recently, Leão et al. [92], reported the occurrence of TTX associated to 613 marine Vibrio spp. in bivalves from the Galician Rias, while Turner et al. [45] found 614 high levels of TTX in a new invasive nemertean species in England. In the

615 Mediterranean Sea, the toxin has been reported in specimens of L. sceleratus caught in 616 the Aegean Sea in 2007 [39] and along the Spanish coast in 2014 [37], as well as in 617 specimens of Mytilus galloprovincialis and Venus verrucosa caught in the seas of 
618 Greece in different periods (2006-2012, 2012 and 2014) [19] and, more recently, in 619 shellfish from Northern and Southern Italy [93-94]. These findings highlight the need of 620 a new risks based approach to control this food safety issues, also considering that until 621 now a maximum TTX level in seafood has not been established by the eurrent European 622 legislation [17]. Currently, EU regulation only manages the risk by prohibiting the 623 marketing of fishery products obtained from fish of the Tetraodontidae families, 624 Molidae, Diodontidae and Canthigasteridae [32], thus not yet considering the other 625 product categories that could potentially carry the TTX. It is likely that the presence of TTX was favoured by different factors such as

627 global warming (Danovaro, Umani, and Pusceddu 2009) and the "Lessepsian" migration 628 of tropical species, including pufferfish species, which transported TTX and TTX 629 producing bacteria to new areas (Akyol et al. 2005; Bentur et al. 2008; Corsini et al. 2006; Katikou et al. 2009; Por 2012; Rambla-Alegre et al. 2017; M. J. Silva et al. 2012).

631 In fact, until 2005 TTX distribution mainly affected the warm waters of Southeast Asia 632 (Bane et al. 2016).

Such discovery inevitably has an impact on food safety, as it has determined the need to manage a risk linked to a new toxin previously not subject to adequate regulation (Rodriguez et al. 2008). In fact, there are no Health Based Guideline Values (HBGVs) for TTX worldwide and noa maximum TTX levels in seafood in the EU has 637 nit been established by the current European legislation (EFSA CONTAM Panel 2017). 638 which EU regulation manages the risk only by prohibiting the marketing of fishery 639 products obtained from fish of the Tetraodontidae families, Molidae, Diodontidae and 640 Canthigasteridae (Reg. (CE) No. 853/2004), not considering the other product 641 eategories that could potentially carry the TTX.

642 5. Conclusions 
The present study shows that different food products and geographical context

644 influence the risk of TTX intoxication.

TTX poisoning is confirmed to be a main issue in South East and East Asia. In

646 this geographical area most of the cases where described following the ingestion of all 647 the seafood product categories (fish, gastropods, arthropods, cephalopods). 648 Interestingly, it was the only geographical sub-area where intoxications from $C$. 649 rotundicauda (arthropod) and Hapalochlaena spp. (cephalopod) were reported. In 650 Oceania, Sub-Saharan Africa and Central-South America the poisoning cases were 651 caused exclusively by pufferfish, with sporadic frequency and mainly during family 652 consumption of locally caught specimens. In North America, where cases were 653 described exclusively in the United States, the consumption of illegally imported or 654 mislabeled Asian products was generally implicated. The same occurred for the few 655 dated intoxications reported historically in Europe. However, the recent spread of TTX 656 towards new marine environments, such as the Mediterranean Sea and the Atlantic 657 Ocean, represent an emerging risk in Europe, in Middle East countries and North 658 Africa, as confirmed by the recent cases of intoxication in these regions. Even though, in view of the large geographical area and period of time analyzed,

660 it is possible that a few cases reported in grey literature might have escaped the analysis, 661 outcomes from this comprehensive global survey furnish an update scenario on TTX 662 intoxication according to geographical area and the implicated seafood. It therefore 663 represents a useful source of data to feed risk assessment by taking into account the 664 changing environmental and anthropogenic factors. Consequently, risk management 665 should be updated, also considering that there are no Health Based Guideline Values for 666 TTX worldwide. Beside issuing updated regulation, increasing awareness of all the 
667 stakeholders, such as policy makers, food business operators and consumers is strongly 668 needed.

669

Even though, in view of the large geographical area and period of time analysed,

671 it is possible that a few cases reported in grey literature might have escaped the analysis,

this work represents the first comprehensive global survey, providing epidemiological data useful for risk assessment.

TTX intoxication is confirmed to be a main issue in South East and East Asia,

675 where most of the intoxications where described. Intoxications occurred in this sub-area 676 derived from the widest variety of product categories: beside fish, which was common 677 to all geographic areas investigated, most of the intoxications caused by marine 678 gastropods occurred in South East and East Asia, which was also the only geographical 679 sub-area where intoxications from C. rotundicauda (arthropod) and Hapalochlaena spp. 680 (cephalopod) were reported. In North America cases were described exclusively in the United States, mainly 682 due to the consumption of illegally imported or mislabelled Asian products. Similarly, the few dated intoxications reported historically in Europe were all referable to

684 mistabelled products imported from Asia. However, the present study highlights the 685 spread of TTX towards new marine environments, as confirmed by the recent cases of 686 intoxication, occurred in Europe (Spain), in Middle East countries (Israel and Lebanon) 687 and North Africa (Egypt, Moroceo and Tunisia). Therefore, there is a strong need to reassess the risk related to TTX intoxication, taking into account the changed 689 environmental and anthropogenic factors.

\section{Word count:}

6916942 
692 Funding

693 This study was supported by the Italian Ministry of Health (Current Research Grant IZS

694 LT 08/14 RC).

695 Contribution of authors

696 LG: study selection and data extraction and writing review; AM: bibliographic search,

697 study selection and data extraction; DN: statistical analysis; VM: revision of the

698 manuscript; LG: bibliographic search; AA: experimental design, supervising of all

699 phases and writing review.

700 Declaration of interest statement

701 No conflict of interest to declare

702 Acknowledgments

703 The authors wish to thank Dr. Lara Tinacci for drawing the image representing

704 pufferfish anatomy in Figure 4.

705

706

707

708

709

710

711

712

713

714

715

716

717 


\section{References}

1. Hwang, D. F.; Noguchi, T. Tetrodotoxin poisoning. Advances in Food Nutrition and Research 2007, 52, 142-236.

2. Isbister, G. K.; Kiernan, M. C. Neurotoxic marine poisoning. The Lancet Neurology 2005, 4(4), 219-228.

3. Denac, H.; Mevissen, M.; Scholtysik, G. Structure, function and pharmacology of voltage-gated sodium channels. Naunyn-Schmiedeberg's archives of pharmacology 2000, 362(6), 453-479.

4. Arakawa, O.; Hwang, D. F.; Taniyama, S.; Takayani, T. Toxins of pufferfish that cause human intoxications. Coastal environmental and ecosystem issues of the East China Sea 2010, 227-244.

5. Chew, S. K.; Goh, C. H.; Wang, K. W.; Mah, P. K.; Tan, B. Y. Puffer fish (tetrodotoxin) poisoning: clinical report and role of anti-cholinesterase drugs in therapy. Singapore medical journal 1983, 24(3), 168-171.

6. Chowdhury, F. R.; Ahasan, H. N.; Al Mamun, A.; Rashid, A. M.; Al Mahboob, A. Puffer fish (Tetrodotoxin) poisoning: an analysis and outcome of six cases. Tropical doctor 2007, 37(4), 263-4.

7. Salzman, M.; Madsen, J. M.; Greenberg, M. I. Toxins: bacterial and marine toxins. Clinics in laboratory medicine 2006, 26(2), 397-419.

8. Nagashima, Y.; Arakawa, O. Pufferfish poisoning and tetrodotoxin. Marine and Freshwater Toxins 2016, 259-84.

9. Noguchi, T.; Arakawa, O. Tetrodotoxin-distribution and accumulation in aquatic organisms, and cases of human intoxication. Marine drugs 2008, 6(2), 220-242.

10. Bane, V.; Brosnan, B.; Barnes, P.; Lehane, M.; Furey, A. High-resolution mass spectrometry analysis of tetrodotoxin (TTX) and its analogues in puffer fish and shellfish. Food Additives \& Contaminants: Part A 2016, 33(9), 1468-89.

11. Lin S. J.; Hwang, D. F.; Shao, K. T.; Jeng, S. S. Toxicity of Taiwanese gobies. Fisheries science 2000, 66(3), 547.

12. McNabb, P., Selwood, A. I.; Munday, R.; Wood, S. A.; Taylor, D. I.; MacKenzie, L. A.; van Ginkel, R.; Rhodes, L. L.; Cornelisen, C.; Heasman, K. et al. Detection of tetrodotoxin from the grey side-gilled sea slug Pleurobranchaea maculata, and associated dog neurotoxicosis on beaches adjacent to the Hauraki Gulf, Auckland, New Zealand. Toxicon 2010, 56(3), 466-473.

13. Rodriguez, P.; Alfonso, A.; Vale, C.; Alfonso, C.; Vale, P.; Tellez, A.; Botana, L. M. First toxicity report of tetrodotoxin and 5, 6, 11-trideoxyTTX in the trumpet shell Charonia lampas lampas in Europe. Analytical chemistry 2008, 80(14), 5622-5629. 
14. Shui, L. M., Chen, K.; Wang, J. Y.; Mei, H. Z.; Wang, A. Z.; Lu, Y. H.; Hwang, D. F. Tetrodotoxin-associated snail poisoning in Zhoushan: a 25-year retrospective analysis. Journal of food protection 2003, 66(1), 110-114.

15. Silva, M.; Azevedo, J.; Rodriguez, P.; Alfonso, A.; Botana, L. M.; Vasconcelos, V. New gastropod vectors and tetrodotoxin potential expansion in temperate waters of the Atlantic Ocean. Marine drugs 2012, 10(4); 712-726.

16. McNabb, P. S.; Taylor, D. I.; Ogilvie, S. C.; Wilkinson, L.; Anderson, A.; Hamon, D.; Wood, S. A.; Peake, B. M. First detection of tetrodotoxin in the bivalve Paphies australis by liquid chromatography coupled to triple quadrupole mass spectrometry with and without precolumn reaction. Journal of AOAC International 2014, 97(2), 325-333.

17. EFSA CONTAM Panel (EFSA Panel on Contaminants in the Food Chain), Knutsen, H. K.; Barregärd, A. J.; Bignami, L.; Brüschweiler, M.; Ceccatelli, B.; Cottrill, S.; Dinovi, B.; Edler, M.; Grasl-Kraupp, L.; Hogstrand, B. et al. Scientific opinion on the risks for public health related to the presence of tetrodotoxin (TTX) and TTX analogues in marine bivalves and gastropods. EFSA Journal 2017, 15(4), 4752.

18. Turner, A. D.; Powell, A.; Schofield, A.; Lees, D. N.; Baker-Austin, C. Detection of the pufferfish toxin tetrodotoxin in European bivalves, England, 2013 to 2014. Eurosurveillance 2015, 20(2), 21009.

19. Vlamis, A., Katikou, P.; Rodriguez, I.; Rey, V.; Alfonso, A.; Papazachariou, A.; Zacharaki, T.; Botana, A. M.; Botana, L. M. First detection of tetrodotoxin in Greek shellfish by UPLC-MS/MS potentially linked to the presence of the dinoflagellate Prorocentrum minimum. Toxins 2015, 7(5), 1779-1807.

20. Wu, Y. J.; Lin, C. L.; Chen, C. H.; Hsieh, C. H.; Jen, H. C.; Jian, S. J.; Hwang, D. F. Toxin and species identification of toxic octopus implicated into food poisoning in Taiwan. Toxicon 2014, 91, 96-102.

21. Tanu, M. B.; Mahmud, Y.; Tsuruda, K.; Arakawa, O.; Noguchi, T. Occurrence of tetrodotoxin in the skin of a rhacophoridid frog Polypedates sp. from Bangladesh. Toxicon 2001, 39(7), 937-941.

22. Hanifin, C. T. The chemical and evolutionary ecology of tetrodotoxin (TTX) toxicity in terrestrial vertebrates. Marine drugs 2010, 8(3), 577-593.

23. Magarlamov, T. Y.; Melnikova, D. I.; Chernyshev, A. V. Tetrodotoxin-producing bacteria: Detection, distribution and migration of the toxin in aquatic systems. Toxins 2017, 9(5), 166.

24. Khor, S.; Wood, S.; Salvitti, L.; Taylor, D.; Adamson, J.; McNabb, P.; Cary, S. Investigating diet as the source of tetrodotoxin in Pleurobranchaea maculata. Marine drugs 2014, 12(1), 1-16. 
25. Chua, H. H.; Chew, L. P. Puffer fish poisoning: a family affair. Medical journal of Malaysia 2009, 64(2), 181-182.

26. Ministry of Health, Labour and Welfare of Japan, 2019, available at: https://www.mhlw.go.jp/topics/syokuchu/poison/animal_01.html Accessed 30/04/2019

27. $\mathrm{Xu}$,

M.

2016 ,

available

at: http://www.newschinamag.com/newschina/articleDetail.do?article_id=910\&section_id= 26\&magazine id $=$ Accessed 30/04/2019

28. Chulanetra, M.; Sookrung, N.; Srimanote, P.; Indrawattana, N.; Thanongsaksrikul, J.; Sakolvaree, Y.; Chongsa-Nguan, M.; Kurazono, H.; Chaicumpa, W. Toxic marine puffer fish in Thailand seas and tetrodotoxin they contained. Toxins 2011, 3(10), 1249-1262.

29. Huang, Y. R.; Yin, M. C.; Hsieh, Y. L.; Yeh, Y. H.; Yang, Y. C.; Chung, Y. L.; Hsieh, C. H. E. Authentication of consumer fraud in Taiwanese fish products by molecular trace evidence and forensically informative nucleotide sequencing. Food Research International 2014, 55, 294-302.

30. Cong, N. H.; Tuan, L. T. Electrodiagnosis in puffer fish poisoning--a case report. Electromyography and clinical neurophysiology 2006, 46(5), 291-294.

31. FDA, 2014, available at: https://www.fda.gov/food/alerts-advisories-safetyinformation/advisory-puffer-fish Accessed: 30/04/2019

32. Regulation EC No 853/2004 of the European Parliament and of the Council of 29 April 2004 Laying Down Specific Hygiene Rules for on the Hygiene of Foodstuffs. Official Journal of the European Union L139: 55.

33. Cohen, N. J.; Deeds, J. R.; Wong, E. S.; Hanner, R. H.; Yancy, H. F.; White, K. D.; Thompson, T. M.; Wahl, I.; Pham, T. D.; Guichard, F. M. et al. Public health response to puffer fish (tetrodotoxin) poisoning from mislabeled product. Journal of Food Protection 2009, 72(4); 810-817.

34. Centers for Disease Control and Prevention (CDC) Tetrodotoxin poisoning associated with eating puffer fish transported from Japan--California, 1996. MMWR - Morbidity and mortality weekly report 1996, 45(19): 389.

35. Food Safety News, 2014, available at: https://www.foodsafetynews.com/2014/01/fdainvestigating-puffer-fish-poisoning-in-virginia/\#.W1WZ5NIzbIX Accessed 03/05/2019

36. Kosker, A. R.; Özogul, F.; Durmus, M.; Ucar, Y.; Ayas, D.; Regenstein, J. M.; Özogul, Y. Tetrodotoxin levels in pufferfish (Lagocephalus sceleratus) caught in the Northeastern Mediterranean Sea. Food Chemistry 2016, 210, 332-337.

37. Rambla-Alegre, M.; Reverté, L. ; del Río, V.; de la Iglesia, P.; Palacios, O.; Flores, C.; Elliott, C. T.; Maillaude, C.; Boundy, M. J.; Harwoodf, D. T. et al. Evaluation of tetrodotoxins in puffer fish caught along the Mediterranean coast of Spain. Toxin profile of Lagocephalus sceleratus. Environmental Research 2017, 158: 1-6. 
38. Guardone, L.; Gasperetti, L.; Maneschi, A.; Ricci, E.; Susini, F.; Guidi, A.; Armani, A. Toxic invasive pufferfish (Tetraodontidae family) along Italian coasts: Assessment of an emerging public health risk. Food Control 2018, 91, 330-338.

39. Katikou, P.; Georgantelis, D.; Sinouris, N.; Ptesi, A.; Fotaras, T. First report on toxicity assessment of the Lessepsian migrant puffer fish Lagocephalus sceleratus (Gmelin, 1789) from European waters (Agean Sea, Greece). Toxicon 2009, 54, 50-55.

40. Rodríguez, P.; Alfonso, A.; Otero, P.; Katikou, P.; Georgantelis, D.; Botana, L. M. Liquid chromatography-mass spectrometry method to detect Tetrodotoxin and Its analogues in the puffer fish Lagocephalus sceleratus (Gmelin, 1789) from European waters. Food Chemistry 2012, 132(2), 1103-1111.

41. Kırımer, N.; Göker, F.; Özbek, E. Ö.; Coban, B.; Balcıŏ̆lu, E. B.; Öztürk, B.; Güven, K. C. Tetrodotoxin and fatty acids contents of Lagocephalus sceleratus (Gmelin, 1789) collected in Antalya, Turkey, by MS/MS and GC/MS analyses. Journal of the Black Sea/Mediterranean Environment 2016, 22(3).

42. Kosker, A. R.; Özogul, F.; Ayas, D.; Durmus, M.; Ucar, Y.; Regenstein, J. M.; Özogul, Y. Tetrodotoxin levels of three pufferfish species (Lagocephalus sp.) caught in the North-Eastern Mediterranean Sea. Chemosphere 2019, 219, 95-99.

43. Saoudi, M.; Abdelmouleh, A.; Kammoun, W.; Ellouze, F.; Jamoussi, K.; El Feki, A. Toxicity assessment of the puffer fish Lagocephalus lagocephalus from the Tunisian coast. Comptes rendus biologies 2008, 331(8), 611-616.

44. Kosker, A. R.; Özogul, F.; Durmus, M.; Ucar, Y.; Ayas, D.; Šimat, V.; Özogul, Y. First report on TTX levels of the yellow spotted pufferfish (Torquigener flavimaculosus) in the Mediterranean Sea. Toxicon 2018, 148, 101-106.

45. Turner, A.; Fenwick, D.; Powell, A.; Dhanji-Rapkova, M.; Ford, C.; Hatfield, R.; Santos, A.; Martinez-Urtaza, J.; Bean, T. P.; Baker-Austin, C.; Stebbing, P. New Invasive Nemertean Species (Cephalothrix simula) in England with high levels of tetrodotoxin and a microbiome linked to toxin metabolism. Marine drugs 2018, 16(11), 452.

46. Liu, F. M.; Fu, Y. M.; Shih, D. Y. C. Occurrence of tetrodotoxin poisoning in Nassarius papillosus Alectrion and Nassarius gruneri Niotha. Journal of Food and Drug Analysis 2004, 12(2), 189-192.

47. Ministry of Health, Labour and Welfare of Japan, Pufferfish human poisoning 20032017,

2019, available

at: https:/www.mhlw.go.jp/topics/syokuchu/poison/dl/animal det 01-02.pdf Accessed $30 / 04 / 2019$

48. Ababou, A.; Mosadik, A.; Squali, J.; Fikri, K. O.; Lazreq, C.; Sbihi, A. Intoxication par le poisson coffre [Intoxication by boxfish]. Annales francaises d'anesthesie et de reanimation 2000, 19(3), 188-190. 
49. Liu, S. H.; Tseng, C. Y.; Lin, C. C. Is neostigmine effective in severe pufferfishassociated tetrodotoxin poisoning? Clinical toxicology 2015, 53(1), 13-21.

50. Silva, C. C. P.; Zannin, M.; Rodrigues, D. S.; Santos, C. R. D.; Correa, I. A.; Haddad Junior, V. Clinical and epidemiological study of 27 poisonings caused by ingesting puffer fish (Tetrodontidae) in the states of Santa Catarina and Bahia, Brazil. Revista do Instituto de Medicina Tropical de Sao Paulo 2010, 52(1), 51-56.

51. Yin, H. L.; Lin, H. S.; Huang, C. C.; Hwang, D. F.; Liu, J. S.; Chen, W. H. Tetrodotoxication with Nassauris glans: a possibility of tetrodotoxin spreading in marine products near Pratas Island. The American journal of tropical medicine and hygiene 2005, 73(5), 985-990.

52. Puech, B., Batsalle, B.; Roget, P.; Turquet, J.; Quod, J. P.; Allyn, J.; Idoumbin, P.; Chane-Ming, J.; Villefranque, J.; Mougin-Damour, K. Family tetrodotoxin poisoning in Reunion Island (Southwest Indian Ocean) following the consumption of Lagocephalus sceleratus (Pufferfish). Bulletin de la Société de Pathologie Exotique 2014, 107, 79-84.

53. Kungsuwan, A.; Noguchi, T.; Hashimoto, K.; Nagashima, Y.; Shida, Y.; Suvapeepan, S.; Suwansakornkul, P. Tetrodotoxin in the horseshoe crab Carcinoscorpius rotundicauda inhabiting Thailand. Bulletin of the Japanese Society of Scientific Fisheries (Japan) 1987, 53(2), 261-266.

54. Ngy, L.; Yu, C. F.; Takatani, T.; Arakawa, O. Toxicity assessment for the horseshoe crab Carcinoscorpius rotundicauda collected from Cambodia. Toxicon 2007, 49(6), 843847.

55. Tanu, M. B.; Noguchi, T. Tetrodotoxin as a toxic principle in the horseshoe crab Carcinoscorpius rotundicauda collected from Bangladesh. Food Hygiene and Safety Science (Shokuhin Eiseigaku Zasshi) 1999, 40(6), 426-430.

56. Williams, B. L., Stark, M. R., Caldwell, R. L. Microdistribution of tetrodotoxin in two species of blue-ringed octopuses (Hapalochlaena lunulata and Hapalochlaena fasciata) detected by fluorescent immunolabeling. Toxicon 2012, 60(7), 1307-1313.

57. Williams, B. L.; Caldwell, R. L. Intra-organismal distribution of tetrodotoxin in two species of blue-ringed octopuses (Hapalochlaena fasciata and H. lunulata). Toxicon 2009, 54(3), 345-53.

58. Yotsu-Yamashita, M.; Mebs, D.; Kwet, A.; Schneider, M. Tetrodotoxin and its analogue 6-epitetrodotoxin in newts (Triturus spp.; Urodela, Salamandridae) from southern Germany. Toxicon 2007, 50(2), 306-9.

59. Whitelaw, B. L.; Cooke, I. R.; Finn, J.; Zenger, K.; Strugnell, J. M. The evolution and origin of tetrodotoxin acquisition in the blue-ringed octopus (genus Hapalochlaena). Aquatic toxicology 2018, 206, 114-22. 
60. Islam, M. S.; Luby, S. P.; Rahman, M.; Parveen, S.; Homaira, N.; Begum, N. H.; Khan, K. M. D.; Sultana, R.; Akhter, S.; Gurley, E. S. Social ecological analysis of an outbreak of pufferfish egg poisoning in a coastal area of Bangladesh. The American journal of tropical medicine and hygiene 2011, 85(3), 498-503.

904

905

61. Panão, I.; Carrascosa, C.; Jaber, J. R.; Raposo, A. Puffer fish and its consumption: To eat or not to eat? Food Reviews International 2016, 32(3), 305-322.

62. Cho, H. E.; Ahn, S. Y.; Son, I. S.; In, S.; Hong, R. S.; Kim, D. W.; Woo, S. H.; Moon, D. C.; Kim, S. Determination and validation of tetrodotoxin in human whole blood using hydrophilic interaction liquid chromatography-tandem mass spectroscopy and its application. Forensic science international 2012, 217(1-3), 76-80.

63. Luo, X.; Yu, R. C.; Wang, X. J.; Zhou, M. J. Toxin composition and toxicity dynamics of marine gastropod Nassarius spp. collected from Lianyungang, China. Food Additives \& Contaminants: Part A 2012, 29(1), 117-127.

64. Sui, L. M.; Chen, K.; Hwang, P. A.; Hwang, D. F. Identification of tetrodotoxin in marine gastropods implicated in food poisoning. Journal of natural toxins 2002, 11(3), 213-220.

65. Hwang, P. A.; Tsai, Y. H.; Deng, J. F.; Cheng, C. A.; Ho, P. H.; Hwang, D. F. Identification of tetrodotoxin in a marine gastropod (Nassarius glans) responsible for human morbidity and mortality in Taiwan. Journal of food protection 2005, 68(8), 16961701.

66. Shiu, Y. C.; Lu, Y. H.; Tsai, Y. H.; Chen, S. K.; Hwang, D. F. Occurrence of tetrodotoxin in the causative gastropod Polinices didyma and another gastropod Natica lineata collected from western Taiwan. Journal of Food and Drug Analysis 2003, 11(2), 159-163.

67. Kanchanapongkul, J.; Krittayapoositpot, P. An epidemic of tetrodotoxin poisoning following ingestion of the horseshoe crab Carcinoscorpius rotundicauda. Vertigo 1995, 30: 42 .

68. Ahmed, S. Puffer fish tragedy in Bangladesh: an incident of Takifugu oblongus poisoning in Degholia, Khulna. African Journal of Marine Science 2006, 28(2), 457-458.

69. Islam, Q. T.; Razzak, M. A.; Islam, M. A.; Bari, M. I.; Basher, A.; Chowdhury, F. R.; Sayeduzzaman, A. B. M.; Ahasan, H. A. M. N.; Faiz, M. A.; Arakawa, O. et al. Puffer fish poisoning in Bangladesh: clinical and toxicological results from large outbreaks in 2008. Transactions of the Royal Society of Tropical Medicine and Hygiene 2011, 105(2), $74-80$.

70. Wang, Q.; Zeng, W. W.; Li, K. B.; Chang, O. Q.; Liu, C.; Wu, G. H.; Shi, C. B.; Wu, S. Q. Outbreaks of an iridovirus in marbled sleepy goby, Oxyeleotris marmoratus (Bleeker), cultured in southern China. Journal of fish diseases 2011, 34(5), 399-402. 
71. You, J.; Yue, Y.; Xing, F.; Xia, W.; Lai, S.; Zhang, F. Tetrodotoxin poisoning caused by Goby fish consumption in southeast China: a retrospective case series analysis. Clinics 2015, 70(1), 24-29.

72. Lin, C. L.; Hsieh, C. H.; Hsieh, Y. L.; Tai, Y. C.; Hwang, D. F. Application of LC$\mathrm{MS} / \mathrm{MS}$ in identification of toxin in the causative gastropod and victim samples. Journal of Marine Science and Technology 2013, 21: 52-57.

73. Noguchi, T.; Onuki, K.; Arakawa, O. Tetrodotoxin poisoning due to pufferfish and gastropods, and their intoxication mechanism. ISRN toxicology 2011. doi:10.5402/2011/276939

74. Kanchanapongkul, J. Tetrodotoxin poisoning following ingestion of the toxic eggs of the horseshoe crab Carcinoscorpius rotundicauda, a case series from 1994 through 2006. Southeast Asian Journal of Tropical Medicine and Public Health 2008, 39(2): 303.

75. Robert, R.; Muhammad Ali, S. H.; Amelia-Ng, P. F.Demographics of horseshoe crab populations in Kota Kinabalu, Sabah, Malaysia with emphasis on Carcinoscorpius rotundicauda and some aspects of its mating behaviour. Pertanika Journal of Tropical Agricultural Science 2014, 37(3), 375-388.

76. Cavazzoni, E.; Lister, B.; Sargent, P.; Schibler, A. Blue-ringed octopus (Hapalochlaena sp.) envenomation of a 4-year-old boy: a case report. Clinical Toxicology 2008, 46(8), 760-761.

77. Akyol, O.; Ünal, V.; Ceyhan, T.; Bilecenoglu, M. First confirmed record of Lagocephalus sceleratus (Gmelin, 1789) in the Mediterranean Sea. Journal of Fish Biology 2005, 66(4), 1183-1186.

78. Ben Souissi, J.; Rifi, M.; Ghanem, R.; Ghozzi, L.; Boughedir, W.; Azzurro, E. Lagocephalus sceleratus (Gmelin, 1789) expands through the African coasts towards the Western Mediterranean Sea: a call for awareness. Management 2014, 5(4), 357-362.

79. Neto, S.; de Lima, P.; Aquino, E. C. M. D.; Silva, J. A. D.; Amorim, M. L. P.; Oliveira Júnior, A. E. D.; Júnior H. Envenenamento fatal por baiacu (Tetrodontidae): relato de um caso em criança [Fatal poisoning by puffer fish (Tetrodontidae): report of a case in child]. Revista da Sociedade Brasileira de Medicina Tropical 2010, 92-94.

80. de Souza Simões, E. M.; Mendes, T. M. A.; Adão, A.; Junior V. H. Poisoning after ingestion of pufferfish in Brazil: report of 11 cases. Journal of venomous animals and toxins including tropical diseases 2014, 20(1), 54.

81. Núñez-Vázquez, E. J.; Yotsu-Yamashita, M.; Sierra-Beltrán, A. P.; Yasumoto, T.; Ochoa, J. L. Toxicities and distribution of tetrodotoxin in the tissues of puffer fish found in the coast of the Baja California Peninsula, Mexico. Toxicon 2000, 38(5), 729-734.

82. Ochoa, J. L.; Sánchez-Paz, A.; Cruz-Villacorta, A.; Nunez-Vázquez, E.; Sierra-Beltrán, A. Toxic events in the northwest Pacific coastline of Mexico during 1992-1995: origin 
and impact. In Asia-Pacific Conference on Science and Management of Coastal Environment (pp. 195-200). Dordrecht: Springer, 1997.

83. Sierra-Beltran, A. P.; Cruz, A.; Nunez, E.; Del Villar, L. M.; Cerecero, J.; Ochoa, J. L. An overview of the marine food poisoning in Mexico. Toxicon 1998, 36(11), 1493-1502.

84. Fuhrman, F. A. Tetrodotoxin, tarichatoxin, and chiriquitoxin: historical perspectives. Annals of the New York Academy of Sciences 1986, 479(1), 1-14.

85. Nagashima Y.; Ohta, A.; Yin, X.; Ishizaki, S.; Matsumoto, T.; Doi, H.; Ishibashi, T. Difference in uptake of Tetrodotoxin and Saxitoxins into liver tissue slices among Pufferfish, Boxfish and Porcupinefish. Marine drugs 2018, 16(1), 17.

86. Elshaer, F. M. Comparative histopathological studies on kidney and liver of rat treated by tetrodotoxin (TTX) extracted from gonads and muscles of porcupine fish species. International Journal of Fisheries and Aquatic Studies 2016, 4, 355-360.

87. Sims, J. K.; Ostman, D. C. Pufferfish poisoning: emergency diagnosis and management of mild human tetrodotoxication. Annals of emergency medicine 1986, 15(9), 1094-1098.

88. Deeds, J. R.; White, K. D.; Etheridge, S. M.; Landsberg, J. H. Concentrations of saxitoxin and tetrodotoxin in three species of puffers from the Indian River Lagoon, Florida, the location for multiple cases of saxitoxin puffer poisoning from 2002 to 2004. Transactions of the American Fisheries Society 2008, 137(5), 1317-1326.

89. de Haro, L. Intoxications par organismes aquatiques [Intoxications by aquatic organisms]. Médicine Tropicale 2008, 68, 367-374.

90. Fernández-Ortega, J. F.; Morales-de los Santos, J. M.; Herrera-Gutiérrez, M. E.; Fernández-Sánchez, V.; Loureo, P. R.; Rancaño, A. A.; Téllez-Andrade, A. Seafood intoxication by tetrodotoxin: first case in Europe. The Journal of emergency medicine 2010, 39(5), 612-617.

91. Turner, A.; Dhanji-Rapkova, M.; Coates, L.; Bickerstaff, L.; Milligan, S.; O’Neill, A.; Faulkner, D.; McEneny, H.; Baker-Austin, C.; Lees, D. N.; Algoet, M. Detection of tetrodotoxin shellfish poisoning (TSP) toxins and causative factors in bivalve molluscs from the UK. Marine drugs 2017, 15(9), 277.

92. Leão, J.; Lozano-Leon, A.; Giráldez, J.; Vilariño, Ó.; Gago-Martínez, A. Preliminary results on the evaluation of the occurrence of tetrodotoxin associated to marine Vibrio spp. in bivalves from the Galician Rias (Northwest of Spain). Marine drugs 2018, 16(3), 81.

93. Pigozzi, S.; Ceredi, A.; Pompei, M.; Bordin, P.; Bille, L.; Dell'Aversano, C.; Tartaglione, L.; Sidari, L.; Zanolin, B.; Cacitti, A. et al. First detection of tetrodotoxin in shellfish from Northern Italy. In Proceedings of the Book of abstracts of 6th International Symposium Marine and Freshwater Toxins Analysis, Baiona, Spain, 22-25 October 2017; Abstract no. P8. pp. 60-1. 
1011

1012

1013

1014

1015

1016

1017 Figure captions

1018

1019

1020

1021

1022

1023

1024

1025

1026

1027

1028 the present study. Europe.

94. Dell'Aversano, C.; Tartaglione, L.; Polito, G.; Dean, K.; Giacobbe, M.; Casabianca, S.; Capellacci, S.; Penna, A.; Turner, A. D. First detection of tetrodotoxin and high levels of paralytic shellfish poisoning toxins in shellfish from Sicily (Italy) by three different analytical methods. Chemosphere 2019, 215, 881-892.

Fig. 1 Global map reporting the distribution per country of the cases included in

Fig. 2 Graphic representation of the seafood categories responsible for the case of intoxications collected in the present study.

Fig. 3 Distribution of the seafood categories responsible for the case of intoxications per sub area. SE-E Asia: South East and East Asia; ME-N Africa: Middle East and North Africa; C-S America: Central and South America; SS Africa: Sub-Saharan Africa; OC: Oceania; NAmerica: North America; EU:

Fig. 4 Most relevant fish anatomical part responsible for intoxications 


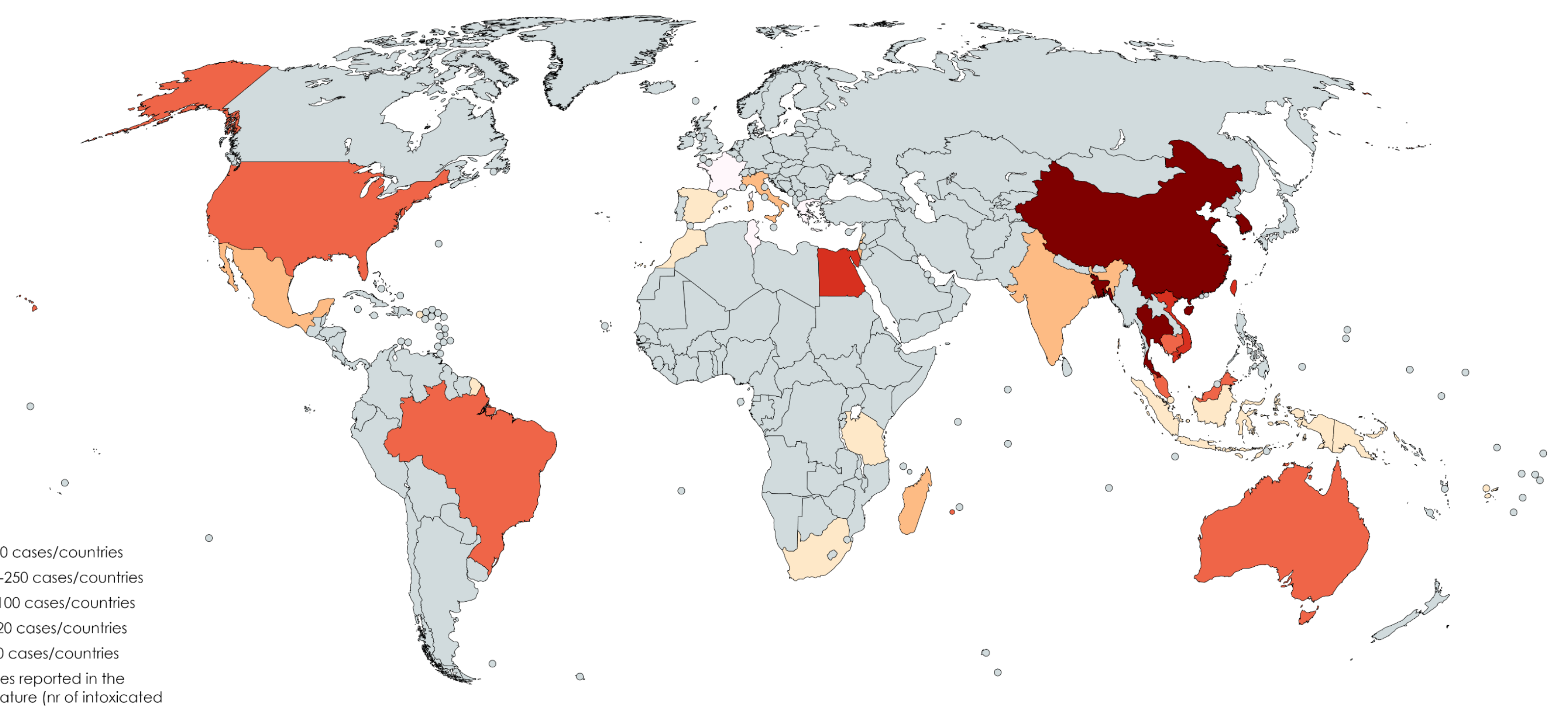

35 literature (nr of intoxicated 36 people not known) 


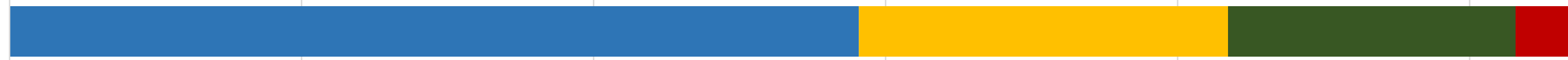




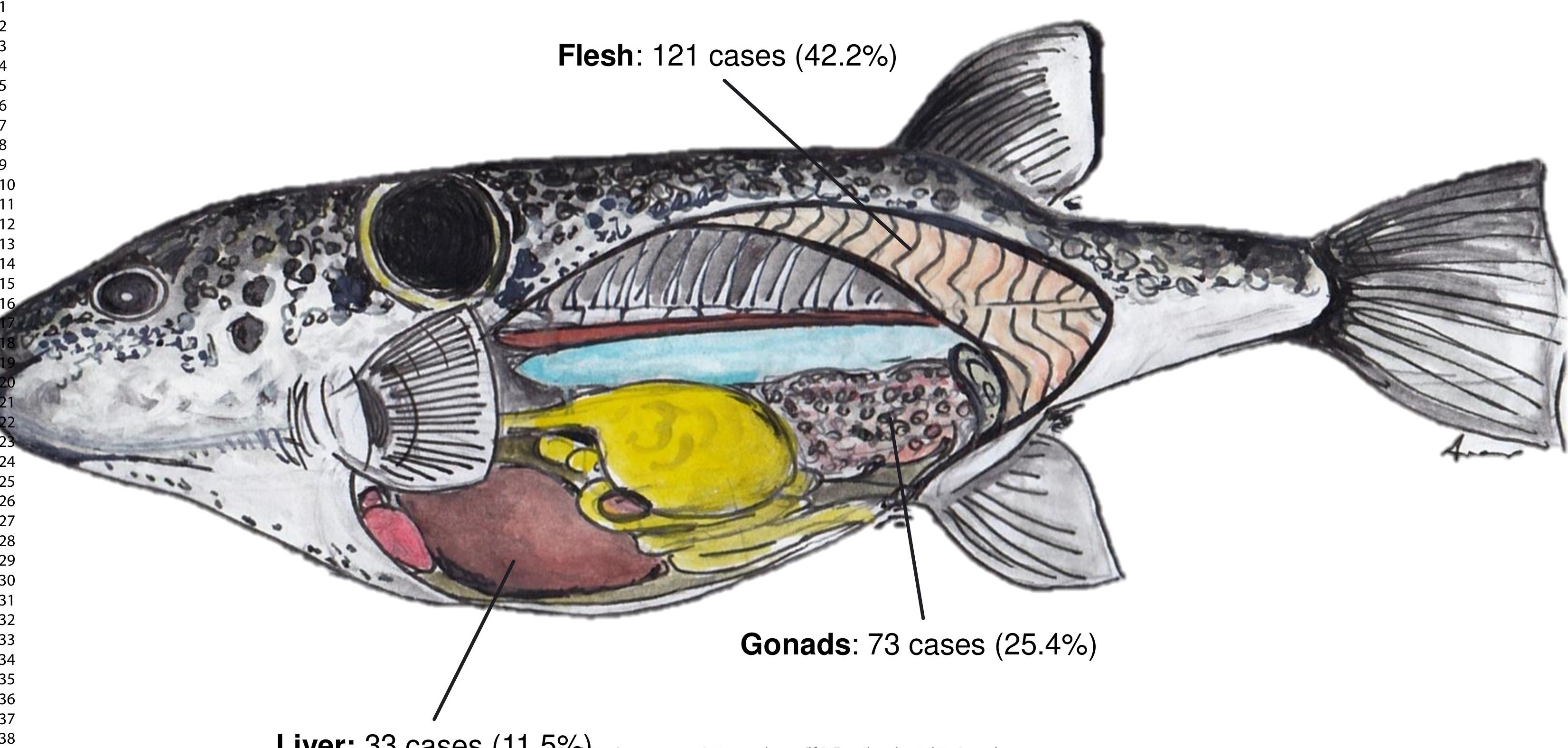

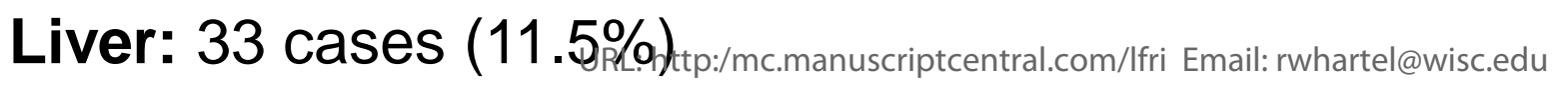


Table 1. Details of the total number of cases of human intoxication by TTX worldwide, divided in non-fatal and fatal cases, according to the different geographical regions and to the different sources of intoxications. ain the case of USA (sub-area North America); *minimum number

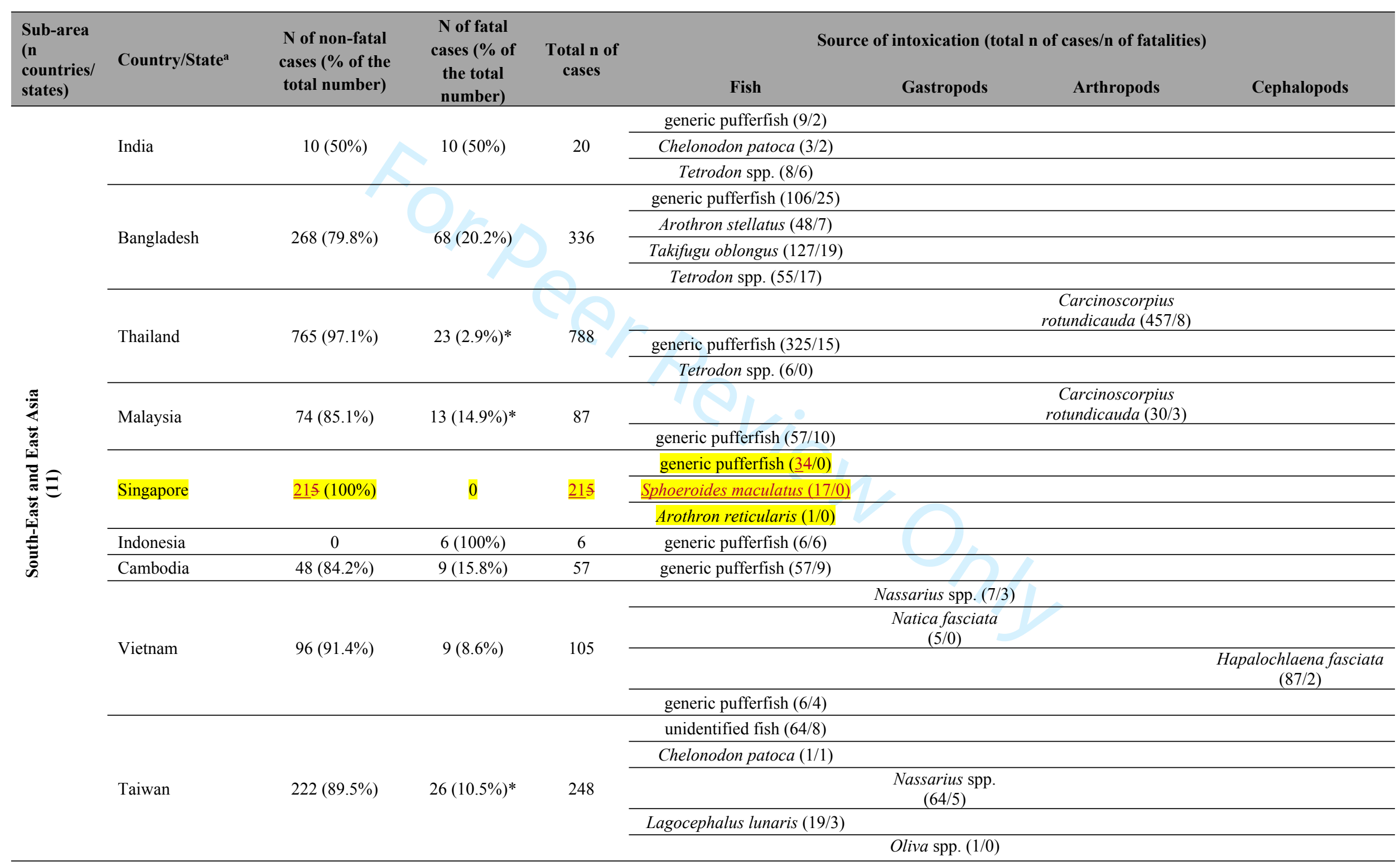




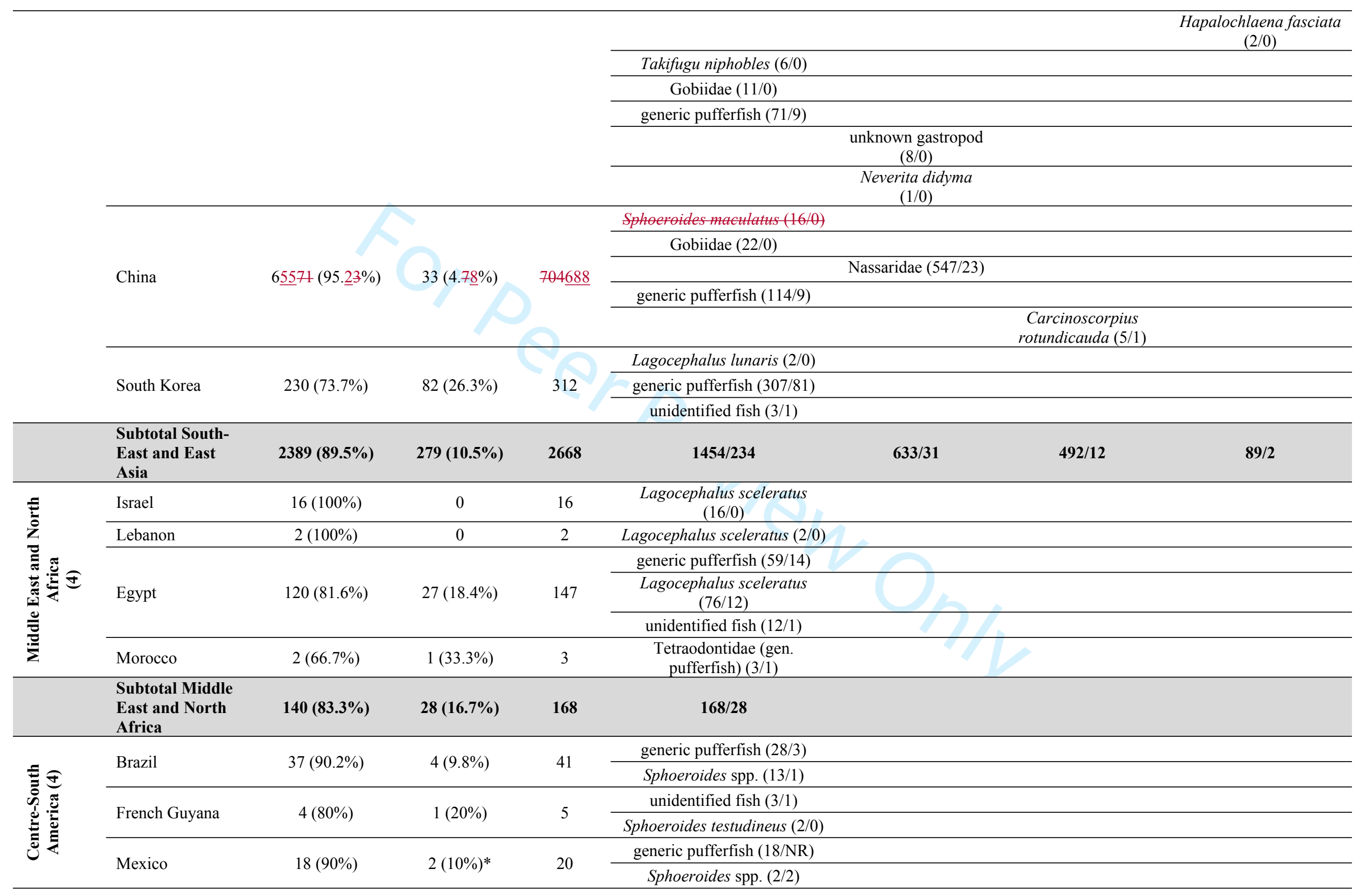




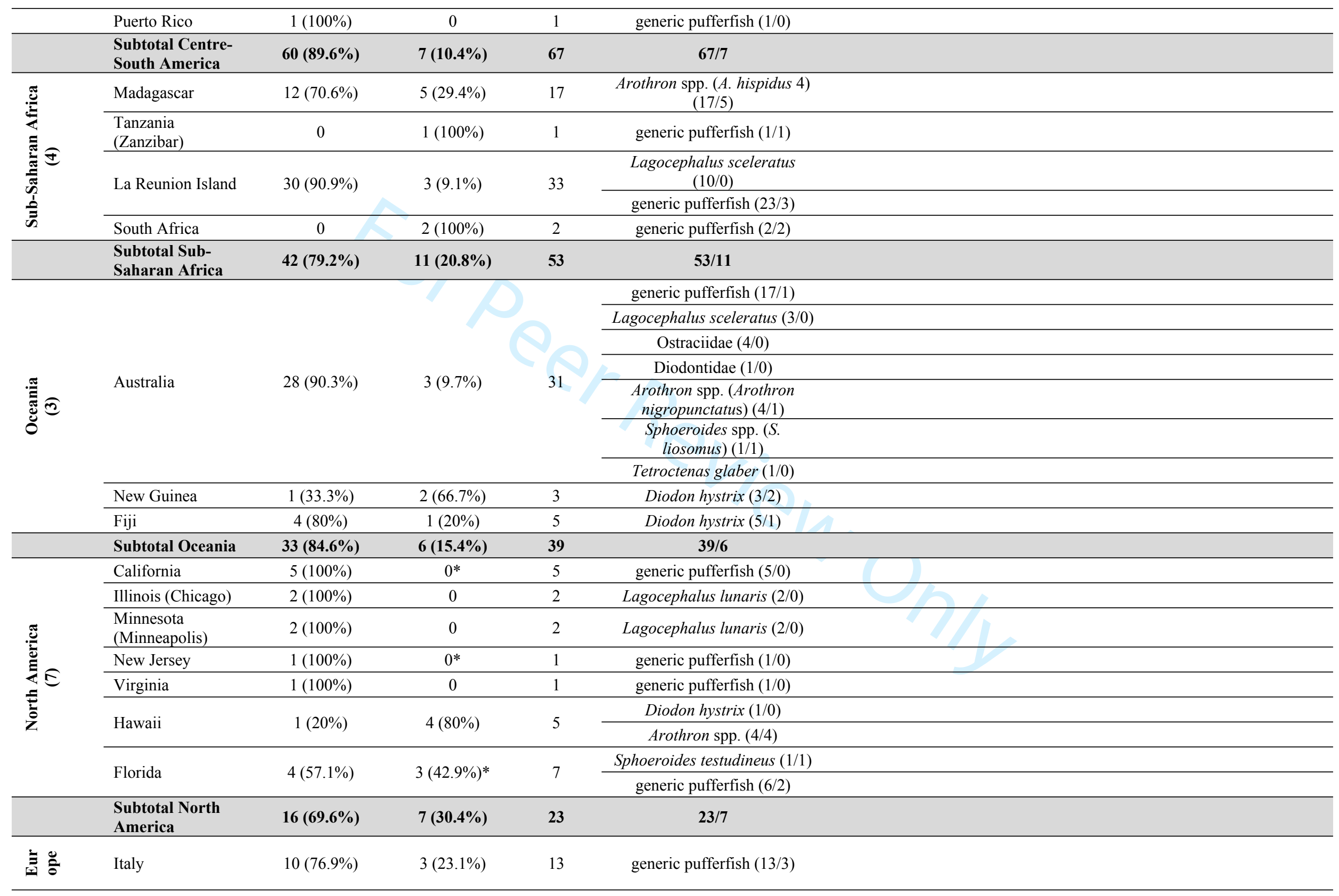




\begin{tabular}{|c|c|c|c|c|c|c|c|c|}
\hline$d$ & Spain & $1(100 \%)$ & 0 & 1 & & $\begin{array}{c}\text { Charonia lampas } \\
(1 / 0)\end{array}$ & & \\
\hline & Subtotal Europe & $11(78.6 \%)$ & $3(21.4 \%)$ & 14 & $13 / 3$ & $1 / 0$ & & \\
\hline & Total & $2691(88.7 \%)$ & $341(11.3 \%)$ & 3032 & 1817 & 634 & 492 & 89 \\
\hline
\end{tabular}


Table 2 Fatality rates across continents and geographical sub-regions. Significant differences are evidenced in the column Difference: same letters indicate non statistically different proportions.

\begin{tabular}{lccc}
\hline Continent & Fatality rate (\%) & Difference & Statistics \\
\hline Asia & 10.5 & $\mathrm{~A}$ & \\
Africa & 19.2 & $\mathrm{~B}$ & \\
America & 15.6 & $\mathrm{~B}$ & $\mathrm{X}^{2}=18,4$ \\
Oceania & 15.4 & $\mathrm{~B}$ & $\mathrm{p}=0,01$ \\
Europe & 21.4 & $\mathrm{~B}$ & \\
\hline Overall mean & 16.4 & Difference & Statistics \\
\hline Sub-areas & Fatality rate (\%) & $\mathrm{A}$ & \\
\hline South-East and East Asia & 10.5 & $\mathrm{~A}$ & \\
Middle East and North Africa & 16.7 & $\mathrm{~B}$ & \\
Sub-Saharan Africa & 20.8 & $\mathrm{~B}$ & $\mathrm{X}^{2}=21,8$ \\
North America & 30.4 & $\mathrm{~A}$ & $\mathrm{p}=0,001$ \\
Centre and South America & 10.4 & $\mathrm{~B}$ & \\
Europe & 21.4 & $\mathrm{~A}$ & \\
Oceania & 15.4 & & \\
\hline Overall mean & 17.9 & &
\end{tabular}


Table 3. Details of the source of intoxication subdivided by taxonomic groups

\begin{tabular}{|c|c|c|c|c|}
\hline Taxonomic group and species & $\begin{array}{l}\text { Total } n \text { of } \\
\text { cases }\end{array}$ & $\%$ & Fatalities & $\%$ \\
\hline Fish & 1817 & 59.9 & 296 & 86.8 \\
\hline Generic "pufferfish" & $12 \underline{3940}$ & 68.3 & 200 & 67.6 \\
\hline Takifugu spp. (Tetraodontidae, Tetraodontiformes) & 133 & 7.3 & 19 & 6.4 \\
\hline Lagocephalus sceleratus (Tetraodontidae, Tetraodontiformes) & 107 & 5.9 & 12 & 4.1 \\
\hline Lagocephalus lunaris (Tetraodontidae, Tetraodontiformes) & 25 & 1.4 & 3 & 1.0 \\
\hline Tetrodon spp. (Tetraodontidae, Tetraodontiformes) & 69 & 3.8 & 23 & 7.8 \\
\hline Arothron spp. (Tetraodontidae, Tetraodontiformes) & 74 & 4.1 & 17 & 5.7 \\
\hline Sphoeroides spp. (Tetraodontidae, Tetraodontiformes) & $3 \underline{6} \overline{5}$ & 1.9 & 5 & 1.7 \\
\hline Chelonodon patoca (Tetraodontidae, Tetraodontiformes) & 4 & 0.2 & 3 & 1.0 \\
\hline Tetroctenas glaber (Tetraodontidae, Tetraodontiformes) & 1 & 0.1 & 0 & 0.0 \\
\hline Diodon spp. (Diodontidae, Tetraodontiformes) & 10 & 0.6 & 3 & 1.0 \\
\hline Ostraciidae (Tetraodontiformes) & 4 & 0.2 & 0 & 0.0 \\
\hline Total Tetraodontiformes & 1703 & 93.7 & 285 & 96.3 \\
\hline Gobiidae (Perciformes) & 33 & 1.8 & 0 & 0.0 \\
\hline Unidentified fish & 82 & 4.5 & 11 & 3.7 \\
\hline Gastropod & 634 & 20.9 & 31 & 9.1 \\
\hline Nassaridae, Neogastropoda & 618 & 97.5 & 31 & 100 \\
\hline Natica fasciata (Naticidae, Littorinimorpha) & 5 & 0.8 & 0 & 0.0 \\
\hline $\begin{array}{l}\text { Charonia lampas (syn. Lampas lampas) (Ranellidae, } \\
\text { Littorinimorpha) }\end{array}$ & 1 & 0.2 & 0 & 0.0 \\
\hline Oliva spp. (Olividae, Neogastropoda) & 1 & 0.2 & 0 & 0.0 \\
\hline Neverita didyma (Naticidae, Littorinimorpha) & 1 & 0.2 & 0 & 0.0 \\
\hline Unknown species & 8 & 1.3 & 0 & 0.0 \\
\hline Arthropod & 492 & 16.2 & 12 & 3.5 \\
\hline Carcinoscorpius rotundicauda (Limulidae, Xiphosuridae) & 492 & 100 & 12 & 100 \\
\hline Cephalopod & 89 & 2.9 & 2 & 0.6 \\
\hline Hapalochlaena fasciata (Octopodidae, Octopoda) & 89 & 100 & 2 & 100 \\
\hline Total & 3032 & & 341 & \\
\hline
\end{tabular}


Table 1SM. Toxicological tests used in the studies included in the analysis

\begin{tabular}{|l|l|}
\hline Toxicological analysis & $\mathbf{N}$ \\
\hline No analysis & 2641 \\
\hline Mouse Bioassay (MBA) & $102^{*}$ \\
\hline MBA and High-Performance Liquid Chromatography (HPLC) & $67^{*}$ \\
\hline MBA and Liquid Chromatography-Mass Spectrometry (LC-MS) & 12 \\
\hline MBA, HPLC and Thin-layer chromatography (TLC) & 43 \\
\hline MBA, HPLC and LC-MS & 8 \\
\hline MBA, HPLC and GC-MS & 12 \\
\hline MBA, HPLC, LC-MS and GC-MS & 1 \\
\hline HPLC & 38 \\
\hline LC-MS & 34 \\
\hline GC-MS & 7 \\
\hline LC-MS and GC-MS & 6 \\
\hline TLC, electrophoresis and HPLC & 7 \\
\hline Enzyme-linked immunosorbent assays (ELISA) & 38 \\
\hline TTX confirmed but test not specified & 16 \\
\hline
\end{tabular}

*test on samples collected from the same seashore area of the poisoning ( $n=8$ in MBA and HPLC and $n=42$ in MBA) 
Table 2SM. Data on the number of cases and fatalities in relation to the geographical region, the source of intoxication, the origin of the source, the year and information on the identification of TTX.

\begin{tabular}{|c|c|c|c|c|c|c|c|c|c|}
\hline $\begin{array}{l}\text { Geographical region } \\
\text { and country/state }\end{array}$ & Source of intoxication & Local & Imported & n.a. & Years & \begin{tabular}{|c|} 
TTX \\
identifie \\
$d$ \\
\end{tabular} & $\begin{array}{l}\text { Number } \\
\text { of cases }\end{array}$ & $\begin{array}{c}\text { Number } \\
\text { of } \\
\text { fatalities }\end{array}$ & References \\
\hline \multicolumn{10}{|l|}{ Europe } \\
\hline Italy & generic pufferfish $(\mathrm{F})$ & 0 & 13 & 0 & $\begin{array}{l}1977- \\
1978\end{array}$ & Yes & 13 & 3 & $\begin{array}{l}\text { Viviani et al., 1978; Pocchiari } \\
1977\end{array}$ \\
\hline Spain & Charonia lampas (G) & 1 & 0 & 0 & 2007 & Yes & 1 & 0 & $\begin{array}{l}\text { Fernandez-Ortega et al., 2010; } \\
\text { Rodriguez et al., } 2008\end{array}$ \\
\hline \multicolumn{10}{|l|}{ North America } \\
\hline California & generic pufferfish $(\mathrm{F})^{* * *}$ & 0 & 5 & 0 & $\begin{array}{l}1996 \\
2006\end{array}$ & No & 5 & $0^{\mathrm{a}}$ & CDC, 1996; Cohen et al., 2009 \\
\hline Illinois (Chicago) & Lagocephalus lunaris $(\mathrm{F})$ & 0 & 2 & 0 & 2007 & Yes & 2 & 0 & Cohen et al., 2009 \\
\hline $\begin{array}{l}\text { Minnesota } \\
\text { (Minneapolis) }\end{array}$ & Lagocephalus lunaris (F) & 0 & 2 & 0 & 2014 & Yes & 2 & 0 & Cole et al., 2014 \\
\hline New Jersey & generic pufferfish $(\mathrm{F}) * * *$ & 0 & 1 & 0 & 2007 & No & 1 & $0^{\mathrm{a}}$ & Cohen et al., 2009 \\
\hline Virginia & generic pufferfish $(\mathrm{F})$ & 0 & 1 & 0 & 2014 & No & 1 & 0 & Report FDA, 2014 \\
\hline \multirow[b]{2}{*}{ Hawaii } & Diodon hystrix $(\mathrm{F})$ & 0 & 0 & 1 & 1986 & No & 1 & 0 & Sisms and Ostman, 1986 \\
\hline & Arothron spp. (F) & 0 & 0 & 4 & $\begin{array}{c}1903- \\
1925 \\
\end{array}$ & No & 4 & 4 & Helfrich, 1963 \\
\hline \multirow{2}{*}{ Florida } & Sphoeroides testudineus $(\mathrm{F})$ & 0 & 0 & 1 & $\begin{array}{c}1954- \\
1955 \\
\end{array}$ & No & 1 & 1 & Benson, 1956 \\
\hline & generic pufferfish $(\mathrm{F})$ & 0 & 0 & 6 & $\begin{array}{l}1951- \\
1974\end{array}$ & No & 6 & $2^{\mathrm{a}}$ & $\begin{array}{l}\text { Benson, 1956; Philips and } \\
\text { Brady, } 1953\end{array}$ \\
\hline \multicolumn{10}{|l|}{$\begin{array}{l}\text { Centre-South } \\
\text { America } \\
\end{array}$} \\
\hline \multirow{2}{*}{ Brasil } & generic pufferfish $(\mathrm{F})$ & 0 & 0 & 28 & $\begin{array}{l}1984- \\
2009\end{array}$ & No & 28 & 3 & $\begin{array}{l}\text { Silva et al., 2010; Haddad et } \\
\text { al., } 2004\end{array}$ \\
\hline & Sphoeroides spp. (F) & 12 & 0 & 1 & n.a., 2008 & No & 13 & 1 & $\begin{array}{l}\text { Neto et al., 2010; de Souza et } \\
\text { al., } 2014 \text {; Ferreira et al., } 2010 .\end{array}$ \\
\hline \multirow{2}{*}{ French Guyana } & unidentified fish $(\mathrm{F})$ & 0 & 0 & 3 & n.a. & Yes & 3 & 1 & Villa et al., 2010 \\
\hline & Sphoeroides testudineus $(\mathrm{F})$ & 2 & 0 & 0 & 1990 & No & 2 & 0 & Hommel et al., 1992 \\
\hline \multirow[t]{2}{*}{ Mexico } & generic pufferfish $(\mathrm{F})$ & 0 & 0 & 18 & $\begin{array}{c}1970- \\
1996\end{array}$ & No & 18 & $2^{\mathrm{a}}$ & Sierra-Beltran et al., 1998 \\
\hline & Sphoeroides spp. (F) & 0 & 0 & 2 & 1995 & No & 2 & 2 & Ochoa et al., 1997 \\
\hline Puerto Rico & generic pufferfish $(\mathrm{F})$ & 0 & 0 & 1 & n.a. & No & 1 & 0 & Joy-Sobrino et al., 1985 \\
\hline Oceania & & & & & & & & & \\
\hline
\end{tabular}




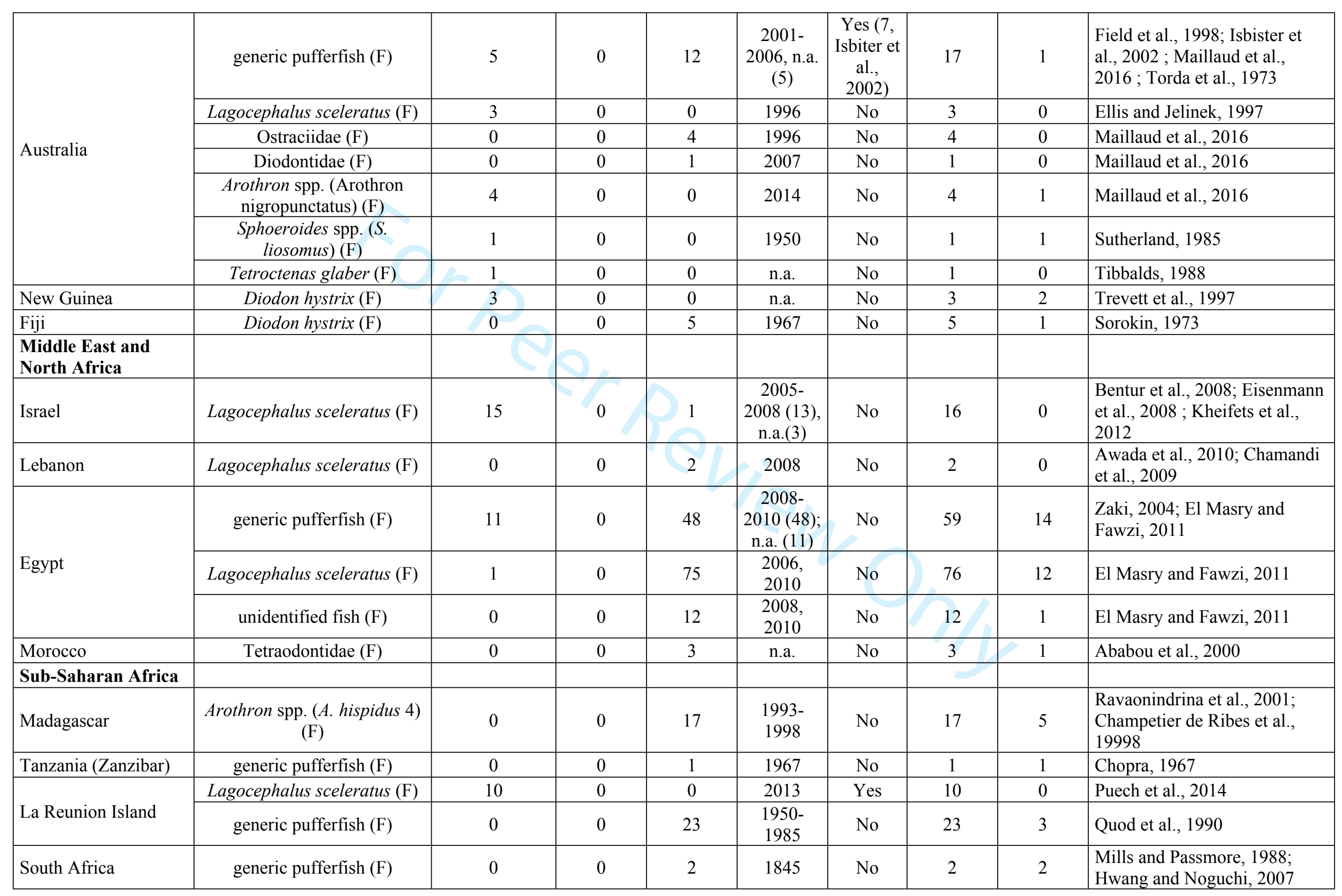




\begin{tabular}{|c|c|c|c|c|c|c|c|c|c|}
\hline Asia & & & & & & & & & \\
\hline \multirow{3}{*}{ India } & generic pufferfish $(\mathrm{F})$ & 0 & 0 & 9 & $\begin{array}{c}2007- \\
2008 ; \text { n.a. }\end{array}$ & No & 9 & 2 & $\begin{array}{l}\text { Behera et al., 2008; Chandra } \\
\text { Sekaran et al., } 2010\end{array}$ \\
\hline & Chelonodon patoca $(\mathrm{F})$ & 3 & 0 & 0 & 1954 & No & 3 & 2 & Jones, 1956 \\
\hline & Tetrodon spp. (F) & 6 & 0 & 2 & $\begin{array}{l}1942- \\
1950\end{array}$ & No & 8 & 6 & Jones, 1956 \\
\hline \multirow{4}{*}{ Bangladesh } & generic pufferfish (F) & 43 & 0 & 63 & $\begin{array}{l}2001- \\
2014\end{array}$ & $\begin{array}{l}\text { Yes (10, } \\
\text { Islam } \\
\text { QT et } \\
\text { al., } \\
2011)\end{array}$ & 106 & 25 & $\begin{array}{l}\text { Islam QT et al., 2011; Islam } \\
\text { MS et al., 2011; Chowdury et } \\
\text { al., } 2007 \text {; Chowdury, Hasan et } \\
\text { al., } 2007\end{array}$ \\
\hline & Arothron stellatus $(\mathrm{F})$ & 48 & 0 & 0 & 2008 & No & 48 & 7 & Islam QT et al., 2011 \\
\hline & Takifugu oblongus (F) & 127 & 0 & 0 & $\begin{array}{l}1998- \\
2008\end{array}$ & $\begin{array}{c}\text { Yes (38, } \\
\text { Islam } \\
\text { QT et } \\
\text { al., } \\
2011,8 \\
\text { Mahmu } \\
\text { d et al., } \\
\text { 1999) }\end{array}$ & 127 & 19 & $\begin{array}{l}\text { Islam QT et al., 2011; Ahmed, } \\
2006 \text {; Mahmud et al., } 1999\end{array}$ \\
\hline & Tetrodon spp. (F) & 29 & 0 & 26 & $\begin{array}{l}1988- \\
1996\end{array}$ & No & 55 & 17 & Mahmud et al., 2000 \\
\hline \multirow{3}{*}{ Thailand } & $\begin{array}{l}\text { Carcinoscorpius } \\
\text { rotundicauda }(\mathrm{A})\end{array}$ & 0 & 0 & $457 *$ & $\begin{array}{l}1994- \\
2014 \\
\end{array}$ & No & 457 & 8 & $\begin{array}{l}\text { Kanchanapongkul, 2008; Joob } \\
\text { et al., } 2015\end{array}$ \\
\hline & generic pufferfish (F) & at least 140 & 0 & 185 & $\begin{array}{l}1989- \\
2008, \text { n.a. } \\
\quad(30)\end{array}$ & No & $325^{\mathrm{a}}$ & $15^{\mathrm{a}}$ & $\begin{array}{l}\text { Chulanetra et al., 2011; } \\
\text { Samitsuwan et al., 2005; } \\
\text { Kanchanapongkul, 2001; } \\
\text { Kanchanapongkul, 2009; } \\
\text { Kanchanapongkul and } \\
\text { Tatraphon, } 1993\end{array}$ \\
\hline & Tetrodon spp. (F) & 6 & 0 & 0 & 1988 & No & 6 & 0 & Laobripathr et al., 1990 \\
\hline \multirow[b]{2}{*}{ Malaysia } & $\begin{array}{l}\text { Carcinoscorpius } \\
\text { rotundicauda }(\mathrm{A})\end{array}$ & 30 & 0 & 0 & 2011 & Yes (7) & 30 & 3 & Suleiman et al., 2017 \\
\hline & generic pufferfish (F) & 26 & 0 & 31 & $\begin{array}{c}1987- \\
2008 \\
\text { n.a.(5) } \\
\end{array}$ & No & 57 & $10^{\mathrm{a}}$ & $\begin{array}{l}\text { Chua and Chew, 2009; Loke } \\
\text { and Tan, 1997; Chan and } \\
\text { David, 1987, Lyn } 1985\end{array}$ \\
\hline \multirow{3}{*}{ Singapore } & generic pufferfish $(\mathrm{F})$ & 0 & 0 & $\underline{3} 4$ & $\begin{array}{l}1982(1) \\
\text { n.a. (3) }\end{array}$ & No & $\underline{3} 4$ & 0 & $\begin{array}{l}\text { Phua, 2013; Yong et al., 2013; } \\
\text { Tan, } 1980 \text {; Chew et al., } 1983\end{array}$ \\
\hline & Sphoeroides maculatus (F) & $\underline{0}$ & $\underline{0}$ & $\underline{1}$ & $\underline{1982}$ & $\underline{\underline{N o}}$ & $\underline{1}$ & $\underline{0}$ & Chew et al., 1983 \\
\hline & Sphoeroides maculatus $(\mathrm{F})$ & $\underline{0}$ & $\underline{0}$ & 16 & n.a. & No & 16 & $\underline{0}$ & Chew et al., 1984 \\
\hline
\end{tabular}




\begin{tabular}{|c|c|c|c|c|c|c|c|c|c|}
\hline & Arothron reticularis $(\mathrm{F})$ & 0 & 0 & 1 & n.a. & No & 1 & 0 & Tambyah et al., 1994 \\
\hline Indonesia & generic pufferfish $(\mathrm{F})$ & 6 & 0 & 0 & 2001 & No & 6 & 6 & Kungsuwan et al., 2001 \\
\hline \multirow{3}{*}{ Vietnam } & Nassarius spp. (G) & 7 & 0 & 0 & $\begin{array}{l}2006- \\
2007 \\
\end{array}$ & \multirow{2}{*}{$\begin{array}{c}\text { Yes (12, } \\
\text { Ha \& } \\
\text { Sato, } \\
2010) \\
\end{array}$} & 7 & 3 & Ha and Sato, 2010 \\
\hline & Natica fasciata $(\mathrm{G})$ & 5 & 0 & 0 & 2007 & & 5 & 0 & Ha and Sato, 2010 \\
\hline & Hapalochlaena fasciata (C) & 87 & 0 & 0 & 2004 & No & 87 & 2 & Williams, 2008 \\
\hline & Chelonodon patoca $(\mathrm{F})$ & 1 & 0 & 0 & 2009 & Yes & 1 & 1 & Wu et al., 2011 \\
\hline Taiwan & Nassarius spp. (G) & 24 & 0 & $40^{* *}$ & $\begin{array}{l}1994- \\
2012\end{array}$ & $\begin{array}{c}\text { Yes (3, } \\
\text { Jen et } \\
\text { al., } \\
2008 ; 1, \\
\text { Lin et } \\
\text { al., } \\
2013 ; 2 \\
\text { Liu et } \\
\text { al., } \\
2004 ; 5 \\
\text { Hwang } \\
\text { Shiu et } \\
\text { al., } \\
2002 ; \\
26 \\
\text { Hwang } \\
\text { et al., } \\
1995 ; 17 \\
\text { Yang et } \\
\text { al., } \\
1995 ; 6 \\
\text { Hwang } \\
\text { et al., } \\
2005 \text { e }\end{array}$ & 64 & $5^{\mathrm{a}}$ & $\begin{array}{l}\text { Lin et al., 2013; Yang et al., } \\
\text { 1995; Hwang et al., 1995; } \\
\text { Hwang et al., 2005; Yin et al., } \\
\text { 2005; Hwang Shiu et al., } \\
\text { 2002; Liu et al., 2004; Jen et } \\
\text { al., } 2008\end{array}$ \\
\hline
\end{tabular}




\begin{tabular}{|c|c|c|c|c|c|c|c|c|c|}
\hline & & & & & & $\begin{array}{l}\text { Yin et } \\
\text { al., } \\
2005)\end{array}$ & & & \\
\hline & Lagocephalus lunaris $(\mathrm{F})$ & 6 & 0 & $13 *$ & $\begin{array}{l}1988- \\
2008\end{array}$ & $\begin{array}{c}\text { Yes }(6, \\
\text { How et } \\
\text { al., } \\
2003 ; 1 \\
\text { Hsieh et } \\
\text { al., } \\
2003 ; 5 \\
\text { Hwang } \\
\text { et al., } \\
2002 ; 3 \\
\text { Wu et } \\
\text { al., } \\
2008) \\
\end{array}$ & 19 & $3^{\mathrm{a}}$ & $\begin{array}{l}\text { Wu et al., 2008; Yang, Liao } \\
\text { and Deng 1996; Hwang et al., } \\
\text { 2002; Hsieh et al., 2003; How } \\
\text { et al., 2003; Tsai et al., } 2006\end{array}$ \\
\hline & Oliva spp. (G) & 0 & 0 & 1 & 2002 & Yes & 1 & 0 & Hwang et al., 2003 \\
\hline & Hapalochlaena fasciata $(\mathrm{C})$ & 0 & 0 & $2 *$ & 2010 & Yes & 2 & 0 & Wu et al., 2014 \\
\hline & Takifugu niphobles $(\mathrm{F})$ & 5 & 0 & 1 & $\begin{array}{l}\text { n.a.; } 2000 \\
\quad(5)\end{array}$ & $\begin{array}{l}\text { Yes }(5, \\
\text { Hsieh et } \\
\text { al., } \\
2002)\end{array}$ & 6 & 0 & $\begin{array}{l}\text { Hsieh et al., 2002; Chen et al., } \\
2010\end{array}$ \\
\hline & Gobidae (F) & 2 & 0 & 8 & $\begin{array}{c}1994- \\
1998\end{array}$ & $\begin{array}{l}\text { Yes }(1 \\
\text { Lan et } \\
\text { al., } \\
1999) \\
\end{array}$ & 11 & 0 & $\begin{array}{l}\text { Lan et al., 1999; Lin et al., } \\
1999 \text {; Yang, Liao and Deng, } \\
1996 \text {; Hwang and Noguchi, } \\
2007 \text {; Lin and Hwang, } 2012\end{array}$ \\
\hline & generic pufferfish $(\mathrm{F})$ & 0 & 0 & 71 & $\begin{array}{l}1988- \\
2003\end{array}$ & No & 71 & 9 & $\begin{array}{l}\text { Yang, Liao and Deng, 1996; } \\
\text { Hwang \& Noguchi, 2007; Lin } \\
\text { and Hwang, } 2012\end{array}$ \\
\hline & unknown gastropod $(\mathrm{G})$ & 0 & 0 & 8 & 2009 & No & 8 & 0 & Lin et al., 2013 \\
\hline & Neverita didyma $(\mathrm{G})$ & 0 & 0 & 1 & 2000 & Yes & 1 & 0 & Shiu et al., 2003 \\
\hline \multirow{4}{*}{ China } & Sphoeroides maculatus (F) & $\theta$ & $\theta$ & 16 & A.a. & $\mathrm{Ne}$ & 16 & $\theta$ & Chew et al., 1984 \\
\hline & Gobidae $(\mathrm{F})$ & 22 & 0 & 0 & 2012 & Yes & 22 & 0 & You et al., 2015 \\
\hline & Nassaridae (G) & $340^{* *}$ & 0 & $207 . .0 .0$ & $\begin{array}{l}1977- \\
2005\end{array}$ & $\begin{array}{l}\text { Yes }(31, \\
\text { Sui et } \\
\text { al., } \\
2002)\end{array}$ & 547 & 23 & $\begin{array}{l}\text { Shui et al., 2003; Sui et al., } \\
\text { 2002; Takatani et al., 2005; } \\
\text { Zhang et al., } 2007 \text {; Wang et } \\
\text { al., } 2008\end{array}$ \\
\hline & generic pufferfish $(\mathrm{F})$ & 14 & 0 & 100 & $\begin{array}{c}\text { 1992- } \\
\text { 2007; } \\
\text { n.a.(10) }\end{array}$ & $\begin{array}{l}\text { Yes }(2, \\
\text { Chen \& } \\
\text { Huang, }\end{array}$ & 114 & 9 & $\begin{array}{l}\text { Liu et al., 2005; Sun et al., } \\
1994 \text {; Lau et al., } 1995 \text {; Chen }\end{array}$ \\
\hline
\end{tabular}




\begin{tabular}{|c|c|c|c|c|c|c|c|c|c|}
\hline & & & & & & $\begin{array}{c}2013 ; 4 \\
\text { Wan et } \\
\text { al., } \\
2007) \\
\end{array}$ & & & $\begin{array}{l}\text { \& Huang, } 2013 \text {; Wan et al., } \\
2007 \text {; Liu et al., } 2011\end{array}$ \\
\hline & $\begin{array}{l}\text { Carcinoscorpius } \\
\text { rotundicauda }(\mathrm{A})\end{array}$ & 5 & 0 & 0 & 2014 & Yes & 5 & 1 & Huang et al., 2016 \\
\hline \multirow[b]{2}{*}{ South Korea } & Lagocephalus lunaris $(\mathrm{F})$ & 0 & 0 & $2 *$ & n.a. & No & 2 & 0 & $\mathrm{Wi}, 2013$ \\
\hline & generic pufferfish (F) & 0 & 0 & 307 & $\begin{array}{c}1971- \\
2011 ; \text { n.a. } \\
\text { (1) }\end{array}$ & No & 307 & 81 & $\begin{array}{l}\text { Hyun et al., 2011; Kim et al., } \\
\text { 2003; Lee \& Kim, } 1987 \text {; Mun } \\
\text { et al., 1998 ; Wi, } 2012\end{array}$ \\
\hline
\end{tabular}

aminimum number; *considering its geographical distribution, the origin may be considered local; **considering the local tradition of eating fresh nassariids, the origin may be considered local; ***two cases in California in 2006 and one in New Jersey in 2007 probably due to Lagocephalus lunaris.

\section{References}

Ababou, A., Mosadik, A., Squali, J., Fikri, K. O., Lazreq, C., \& Sbihi, A. (2000). Intoxication par le poisson coffre. In Annales francaises d'anesthesie et de reanimation (Vol. 19, No. 3, pp. 188-190). Elsevier Masson.

Ahmed, S. (2006). Puffer fish tragedy in Bangladesh: an incident of Takifugu oblongus poisoning in Degholia, Khulna. African Journal of Marine Science, 28(2), 457-458.

Awada, A., Chalhoub, V., Awada, L., \& Yazbeck, P. (2010). Coma profond aréactif réversible après intoxication par des abats d'un poisson méditerranéen. Revue neurologique, 166(3), 337-340.

Behera, A., Dash, B. K., \& Barik, B. K. (2008). Rare puffer fish poisoning-A case report. Medico-Legal Update, 8(2), 5-6.

Benson, J., (1956). Tetradon (blowfish) poisoning. A report of two fatalities. J Forensic Sci, 1, 119-126.

Bentur, Y., Ashkar, J., Lurie, Y., Levy, Y., Azzam, Z. S., Litmanovich, M., ... \& Eisenman, A. (2008). Lessepsian migration and tetrodotoxin poisoning due to Lagocephalus sceleratus in the eastern Mediterranean. Toxicon, 52(8), 964-968.

Centers for Disease Control and Prevention (CDC) (1996). Tetrodotoxin poisoning associated with eating puffer fish transported from Japan--California, 1996. MMWR. Morbidity and mortality weekly report, 45(19), 389.

Chamandi, S. C., Kallab, K., Mattar, H., \& Nader, E. (2009). Human poisoning after ingestion of puffer fish caught from Mediterranean Sea. Middle East journal of anesthesiology, 20(2), 285-288.

Chan, M. K., \& David, P. (1987). Nine fatal cases of puffer fish poisoning in Sabah, Malaysia. Med. J. Malaysia 42(3) 199-200

Champetier de Ribes, G., Ranaivoson, G., Ravaonindrina, N., Rakotonjanabelo, A. L., Rasolofonirina, N., Roux, J., \& Yasumoto, T. (1998). Un problème de santé réémergent à Madagascar: les intoxications collectives par consommation d'animaux marins (1993-1998). Archives de l'Institut Pasteur de Madagascar, 64(1).

Chandrasekaran, V., Pothapregada, S., \& Subramanian, M. (2010). Fish egg poisoning: An unusual cause of respiratory paralysis. Indian journal of pediatrics, 77(4), 462-462.

Chen HYH, Juan CHW, Kao TL, Liu CHY. (2010) Central nervous system effects of puffer fish (Tetrodotoxin) poisoning. J Emerg Crit Care Med; $21: 162$ - 166.

Chen, L., \& Huang, G. Z. (2013). Poisoning by toxic animals in China-18 autopsy case studies and a comprehensive literature review. Forensic science international, 232(1), e12-e23.

Chew, S. K., Chew, L. S., Wang, K. W., Mah, P. K., \& Tan, B. Y. (1984). Anticholinesterase drugs in the treatment of tetrodotoxin poisoning. The Lancet, 324(8394), 108. 
Chew, S. K., Goh, C. H., Wang, K. W., Mah, P. K., \& Tan, B. Y. (1983). Puffer fish (tetrodotoxin) poisoning: clinical report and role of anti-cholinesterase drugs in therapy. Singapore Med J, 24(3), 168-71.

Chi, T., \& Wu, P. H. (2001). A food poisoning incident in Tainan City high school students. Epidemiology Bulletin, 17(1), 1-7.

Cho, H. E., Ahn, S. Y., Son, I. S., In, S., Hong, R. S., Kim, D. W., ... \& Kim, S. (2012). Determination and validation of tetrodotoxin in human whole blood using hydrophilic interaction liquid chromatography-tandem mass spectroscopy and its application. Forensic science international, 217(1-3), 76-80.

Chopra, S. A. (1967). A case of fatal puffer-fish poisoning in a Zanzibari fisherman. East African medical journal, 44, 493-496

Chowdhury, F. R., Ahasan, H. N., Al Mamun, A., Rashid, A. M., \& Al Mahboob, A. (2007a). Puffer fish (Tetrodotoxin) poisoning: an analysis and outcome of six cases. Tropical doctor, 37(4), 263-264.

Chowdhury, F. R., Nazmul Ahasan, H. A., Mamunur Rashid, A. K., Al Mamun, A., \& Khaliduzzaman, S. M. (2007b). Tetrodotoxin poisoning: a clinical analysis, role of neostigmine and short-term outcome of 53 cases. Singapore Med J, 48(9), 830-833.

Chua, H. H., \& Chew, L. P. (2009). Puffer fish poisoning: a family affair. Medical journal of Malaysia, 64(2), 181-182.

Chulanetra, M., Sookrung, N., Srimanote, P., Indrawattana, N., Thanongsaksrikul, J., Sakolvaree, Y., ... \& Chaicumpa, W. (2011). Toxic marine puffer fish in Thailand seas and tetrodotoxin they contained. Toxins, 3(10), 1249-1262.

Cohen, N. J., Deeds, J. R., Wong, E. S., Hanner, R. H., Yancy, H. F., White, K. D., ... \& Huh, I. (2009). Public health response to puffer fish (tetrodotoxin) poisoning from mislabeled product. Journal of food protection, 72(4), 810-817.

Cole, J. B., Heegaard, W. G., Deeds, J. R., McGrath, S. C., \& Handy, S. M. (2015). Tetrodotoxin poisoning outbreak from imported dried puffer fish--Minneapolis, Minnesota, 2014. MMWR. Morbidity and mortality weekly report, 63(51), 1222-1225.

Cong, N. H., \& Tuan, L. T. (2006). Electrodiagnosis in puffer fish poisoning--a case report. Electromyography and clinical neurophysiology, 46(5), 291-294.

de Souza Simões, E. M., Mendes, T. M. A., Adão, A., \& Junior, V. H. (2014). Poisoning after ingestion of pufferfish in Brazil: report of 11 cases. Journal of venomous animals and toxins including tropical diseases, 20(1), 54

Deng, J. F., Tominack, R. L., Chung, H. M., \& Tsai, W. J. (1991). Hypertension as an unusual feature in an outbreak of tetrodotoxin poisoning. Journal of Toxicology: Clinical Toxicology, 29(1), 71-79.

Eisenman, A., Rusetski, V., Sharivker, D., Yona, Z., \& Golani, D. (2008). An odd pilgrim in the Holy Land. The American journal of emergency medicine, $26(3), 383-\mathrm{e} 3$.

El Masry, M. K., \& Fawzi, M. M. (2011). Tetrodotoxin Versus Ciguatera Fish Poisoning in the Mediterranean Sea. Indian Journal of Forensic Medicine \& Toxicology, 5(2)

Ellis, R. \& Jelinek, G. A. (1997). Never eat an ugly fish: three cases of tetrodotoxin poisoning from Western Australia. Emergency Medicine Australasia, 9(2), 136-142.

Fernández-Ortega, J. F., Morales-de los Santos, J. M., Herrera-Gutiérrez, M. E., Fernández-Sánchez, V., Loureo, P. R., Rancaño, A. A., \& Téllez-Andrade, A. (2010). Seafood intoxication by tetrodotoxin: First case in Europe. The Journal of emergency medicine, 39(5), 612-617.

Ferreira, T. R., Corrêa, I. R. D. S., Hoshino, S. D. S. N., Silva, C. L. Q. D., \& Pardal, P. P. D. O. (2010). Envenomation caused by the consumption of pufferfish liver. Rev. para med, 24(3/4)

Field, J. (1998). Puffer fish poisoning. Emergency Medicine Journal, 15(5), 334-336

Ha, D. V. \& Sato, S. (2012). Toxicity of some marine snails responsible for recent food poisonings in Vietnam. Tap chí Khoa hoc và Công nghệ Biển, 10(3), 89-95.

Haddad Jr, V., Takehara, E. T., Rodrigues, D. S., \& Lastória, J. C. (2004). Envenenamento por baiacus (peixes-bola): revisão sobre o tema. Diagn Tratamento, 9(4), 183-185.

Helfrich, P. (1963) Fish poisoning in Hawaii. Hawaii Med. J., 22, 361. Richiesto nilde 11.01.18 ma dati da Hwang and Noguchi 2007

Hommel, D., Hulin, A., Saignavong, S., \& Desbordes, J. M. (1992). Intoxication Par Le Poisson-Coffre (Tetrodotoxine). Médecine d'Afrique Noire, 39(2).

How, C. K., Chern, C. H., Huang, Y. C., Wang, L. M., \& Lee, C. H. (2003). Tetrodotoxin poisoning. The American journal of emergency medicine, 21(1), 51-54.

Hsieh, Y. W., Shiu, Y. C., Cheng, C. A., Chen, S. K., \& Hwang, D. F. (2002). Identification of toxin and fish species in cooked fish liver implicated in food poisoning. Journal of food science, 67(3), 948-952

Hsieh, Y. W., Hwang, P. A., Pan, H. H., Chen, J. B., \& Hwang, D. F. (2003). Identification of tetrodotoxin and fish species in an adulterated dried mullet roe implicated in food poisoning. Journal of food science, $68(1), 142-146$.

Huang, H. N., Zheng, R. J., Liu, L. L., Zheng, M., \& Li, Z. J. (2016). Determination of Tetrodotoxin in Carcinoscorpius rotundicauda (Horseshoe Crab) by High-Performance Liquid Chromatography-Tandem Mass Spectrometry. Analytical Letters, 49(15), 2377-2383. 
Hwang, D. F., Cheng, C. A., Tsai, Y. H., \& Jeng, S. S. (1995a). Tetrodotoxin associated food poisoning due to unknown fish in Taiwan between 1988-1994. Journal of Pharmaceutical and Biomedical Analysis, 13(9), 165-171.

Hwang, D. F., Cheng, C. A., Tsai, H. T., Shih, D. Y. C., Ko, H. C., Yang, R. Z., \& Jeng, S. S. (1995b). Identification of tetrodotoxin and paralytic shellfish toxins in marine gastropods implicated in food poisoning. Fisheries science, 61(4), 675-679.

Hwang, D. F., Shiu, Y. C., Hwang, P. A., \& Lu, Y. H. (2002b). Tetrodotoxin in gastropods (snails) implicated in food poisoning in northern Taiwan. Journal of food protection, $65(8), 1341-1344$.

Hwang, D.F.; Noguchi T. Tetrodotoxin poisoning. (2007) Adv. Food Nutr. Res., 52, 142-236.

Hyun, S. H., Sohn, C. H., Ryoo, S. M., Oh, B. J., \& Lim, K. S. (2011). Clinical analysis of puffer fish poisoning cases. Journal of the Korean Society of Clinical Toxicology, 9(2), 95-100.

Isbister, G. K., Son, J., Wang, F., Maclean, C. J., Lin, C. S., Ujma, J., ... \& Kiernan, M. C. (2002). Puffer fish poisoning: a potentially life-threatening condition. Medical Journal of Australia, 177(11/12), 650-653.

Islam, M. S., Luby, S. P., Rahman, M., Parveen, S., Homaira, N., Begum, N. H., ... \& Gurley, E. S. (2011a). Social ecological analysis of an outbreak of pufferfish egg poisoning in a coastal area of Bangladesh. The American journal of tropical medicine and hygiene, 85(3), 498-503.

Islam, Q. T., Razzak, M. A., Islam, M. A., Bari, M. I., Basher, A., Chowdhury, F. R., ... \& Yotsu-Yamashita, M. (2011b). Puffer fish poisoning in Bangladesh: clinical and toxicological results from large outbreaks in 2008. Transactions of the Royal Society of Tropical Medicine and Hygiene, 105(2), 74-80.

Jen, H. C., Lin, S. J., Tsai, Y. H., Chen, C. H., Lin, Z. C., \& Hwang, D. F. (2008). Tetrodotoxin poisoning evidenced by solid-phase extraction combining with liquid chromatography-tandem mass spectrometry. Journal of Chromatography B, 871(1), 95-100.

Jones, S. (1956). Some deaths due to fish poisoning (Ichthyosarcotoxism) in India. The Indian journal of medical research, 44(2), 353.

Joob, B., \& Wiwanitkit, V. (2015) Death rate due to horseshoe crab poisoning: summarization on Thai reports. Journal of Coastal Life Medicine; 3(6): 503-504

Joy Sobrino, J. L., Ramírez Ramírez, R., \& Vélez Borrás, J. R. (1985). Puffer fish (tetrodotoxin) poisoning: case report. Bol. Asoc. Méd. P. R, 77(11), 482-5.

Kanchanapongkul, J., \& Tantraphon, W. A. R. A. (1993). Pelagic paralysis from puffer fish poisoning. Journal of the Medical Association of Thailand= Chotmaihet thangphaet, 76(5), 285-287.

Kanchanapongkul, J. (2001). Puffer fish poisoning: clinical features and management experience in 25 cases. Journal of the Medical Association of Thailand= Chotmaihet thangphaet, 84(3), 385-389 dati in Liu et al., 2015

Kanchanapongkul, J. (2008). Tetrodotoxin poisoning following ingestion of the toxic eggs of the horseshoe crab Carcinoscorpius rotundicauda, a case series from 1994 through 2006. Southeast Asian Journal of Tropical Medicine and Public Health, 39(2), 303.

Kanchanapongkul J. [Puffer fish poisoning: a review of 29 cases at Chon Buri Hospital]. (2009). J Health Sci 18(4): 624-632. Thai.

Kheifets, J., Rozhavsky, B., Girsh Solomonovich, Z., Marianna, R., \& Soroksky, A. (2012). Severe tetrodotoxin poisoning after consumption of Lagocephalus sceleratus (pufferfish, fugu) fished in Mediterranean Sea, treated with cholinesterase inhibitor. Case reports in critical care, 2012.

Kim, J. H., Gong, Q. L., Mok, J. S., Min, J. G., Lee, T. S., \& Park, J. H. (2003). Characteristics of Puffer Fish Poisoning Outbreaks in Korea (1991-2002). Journal of Food Hygiene and Safety, 18(3), 133-138.

Kungsuwan A, Ittipong B, Inthuserdha P, Pavitranon S, Teeyapan P, Yooyen A, Loedang S. (2001) Biotoxins analysis in dead fisherman due to ingesting marine puffers. Abstracts of the Seminar on Fisheries 2001; 18-20 September 2001, Bangkok, Thailand. Department of Fisheries.

Lan, M. Y., Lai, S. L., Chen, S. S., \& Hwang, D. F. (1999). Tetrodotoxin intoxication in a uraemic patient. Journal of Neurology, Neurosurgery \& Psychiatry, 67(1), 127-128.

Laobhripatr, S., Limpakarnjanarat, K., Sangwonloy, O., Sudhasaneya, S., Anuchatvorakul, B., Leelasitorn, S., \& Saitanu, K. (1990). Food poisoning due to consumption of the freshwater puffer Tetraodon fangi in Thailand. Toxicon, 28(11), 1372-1375.

Lau, F. L., Wong, C. K., \& Yip, S. H. (1995). Puffer fish poisoning. Journal of accident \& emergency medicine, 12(3), 214.

Lee, Y. W., \& Kim, J. G. (1987). A study on the trend of food poisoning outbreaks, reported cases. Korea. Korean. J. Food Hyg, 2, 215-237.

Lin, S. J., et al. (1999) Acute goby poisoning in southern Taiwan. Journal of natural toxins 8.1 141-147.

Lin, W. F., \& Hwang, D. F. (2012). Analysis of Poisoning Cases, Monitoring and Risk Warning for Marine Toxins (TTX, PSP and CTXs) in Taiwan. Journal of Food \& Drug Analysis, 20(4). 
Lin, C. L., Hsieh, C. H., Hsieh, Y. L., Tai, Y. C., \& Hwang, D. F. (2013). Application of LC-MS/MS in identification of toxin in the causative gastropod and victim samples. Journal of Marine Science and Technology, 21, 52-57.

Liu, F. M., Fu, Y. M., \& Shih, D. Y. C. (2004). Occurrence of tetrodotoxin poisoning in Nassarius papillosus Alectrion and Nassarius gruneri Niotha. Journal of Food and Drug Analysis, 12(2), 189-192.

Liu, G. Z., Che, J. L., Xiao, M., \& Fan, Z. H. (2005). Clinical nature of tetrodotoxin intoxication and the measures for emergency rescue. Di 1 jun yi da xue xue bao= Academic journal of the first medical college of PLA, 25(12), 1521-1523. Dati da Liu et al. 2015

Liu, D., Zhang, J., Han, B., Pen, L., \& Liu, D. (2011). An electrophysiological study of acute tetrodotoxin poisoning. Cell biochemistry and biophysics, 59(1), 13-18.

Loke, Y. K., \& Tan, M. H. (1997). A unique case of tetrodotoxin poisoning. The Medical journal of Malaysia, 52(2), 172-174.

Lyn, P. C. W. (1985). Puffer fish poisoning: four case reports. Medical Journal of Malaysia, 40(1), 31-34.

Mahmud, Y., Tanu, M. B., \& Noguch, T. (1999). First occurrence of a food poisoning incident due to ingestion of Takifugu oblongus, along with a toxicological report on three marine puffer species in Bangladesh. Food Hygiene and Safety Science (Shokuhin Eiseigaku Zasshi), 40(6), 473-480.

Mahmud, Y., Arakawa, O., \& Noguchi, T. (2000). An epidemic survey on freshwater puffer poisoning in Bangladesh. Journal of natural toxins, 9(4), 319-326.

Maillaud, C., Barguil, Y., Saint-Gilles, H. L. C., Mikulski, M., Guittonneau-Leroy, A. L., Pérès, H., \& Nour, M. (2016). Tétrodotoxisme en Nouvelle-Calédonie. Cas cliniques. Toxicologie Analytique et Clinique, 28(1), 57-63.

Mills, A. R., \& Passmore, R. (1988). Pelagic paralysis. The Lancet, 331(8578), 161-164.

Mun, H. S., Kang, S. W., Shin, J. H., Rho, W. K., Park, G. T., Cho, K. S., ... \& Kee, C. S. (1998). A Case of Recovery from Suspended Animation caused by Puffer fish Poisoning: a case report. Journal of the Korean Society of Emergency Medicine, 9(3), 465-470.

Neto, S., de Lima, P., Aquino, E. C. M. D., Silva, J. A. D., Amorim, M. L. P., Oliveira Júnior, A. E. D., \& Júnior, H. (2010). Envenenamento fatal por baiacu (Tetrodontidae): relato de um caso em criança. Revista da Sociedade Brasileira de Medicina Tropical, 92-94.

Ngy, L., Taniyama, S., Shibano, K., Yu, C. F., Takatani, T., \& Arakawa, O. (2008). Distribution of tetrodotoxin in pufferfish collected from coastal waters of Sihanouk Ville, Cambodia. Journal of the Food Hygienic Society of Japan (Japan).

Ochoa, J. L., Sánchez-Paz, A., Cruz-Villacorta, A., Nunez-Vázquez, E., \& Sierra-Beltrán, A. (1997). Toxic events in the northwest Pacific coastline of Mexico during 19921995: origin and impact. In Asia-Pacific Conference on Science and Management of Coastal Environment (pp. 195-200). Springer, Dordrecht.

Phillips, C. \& Brady, W. H. (1953). Sea pests. Marine Lab. Univ. of Miami.

Pocchiari, F. (1977). Trade of misbranded frozen fish: medical and public health implications. Annali dell'Istituto superiore di sanita, 13(Pt. 4), 767-772.

Phua, D. H. (2013, May). Dying for delicacy-tetrodotoxin poisoning from dried preserved puffer fish. Clinical Toxicology (Vol. 51, No. 4, pp. 274-274).

Puech, B., Batsalle, B., Roget, P., Turquet, J., Quod, J. P., Allyn, J., ... \& Vandroux, D. (2014). Family tetrodotoxin poisoning in Reunion Island (Southwest Indian Ocean) following the consumption of Lagocephalus sceleratus (Pufferfish). Bull. Soc. Pathol. Exot, 107, 79-84.

Quod, J. P., Prunaux, O., \& Guignard, A. (1990). Les empoisonnements par poissons tropicaux à La Réunion: synthèse et perspectives. Rev Méd Vét, 141, 1005-1009,

Ravaonindrina, N., Andriamaso, T. H., \& Rasolofonirina, N. (2001). Intoxication après consommation de poisson globe à Madagascar: à propos de 4 cas. Archives de l'Institut Pasteur de Madagascar, 67(1-2), 61-64.

Rodriguez, P., Alfonso, A., Vale, C., Alfonso, C., Vale, P., Tellez, A., \& Botana, L. M. (2008). First toxicity report of tetrodotoxin and 5, 6, 11 -trideoxyTTX in the trumpet shell Charonia lampas lampas in Europe. Analytical chemistry, 80(14), 5622-5629.

Samitsuwan, P.; Sermkaew, T.; Laosiritaworn, Y. (2005). An Outbreak of Poisoning Associated with Puffer Fishes, Bangkok, Thailand, 2002. J. Health Sci. (Thailand), 14, 203208.

Shiu, Y. C., Lu, Y. H., Tsai, Y. H., Chen, S. K., \& Hwang, D. F. (2003). Occurrence of tetrodotoxin in the causative gastropod Polinices didyma and another gastropod Natica lineata collected from western Taiwan. Journal of Food and Drug Analysis, 11(2), 159-163.

Shui, L. M., Chen, K., Wang, J. Y., Mei, H. Z., Wang, A. Z., Lu, Y. H., \& Hwang, D. F. (2003). Tetrodotoxin-associated snail poisoning in Zhoushan: a 25-year retrospective analysis. Journal of food protection, 66(1), 110-114.

Sierra-Beltran, A. P., Cruz, A., Nunez, E., Del Villar, L. M., Cerecero, J., \& Ochoa, J. L. (1998). An overview of the marine food poisoning in Mexico. Toxicon, 36(11), 14931502. 
Silva, C. C. P., Zannin, M., Rodrigues, D. S., Santos, C. R. D., Correa, I. A., \& Haddad Junior, V. (2010). Clinical and epidemiological study of 27 poisonings caused by ingesting puffer fish (Tetrodontidae) in the states of Santa Catarina and Bahia, Brazil. Revista do Instituto de Medicina Tropical de Sao Paulo, 52(1), 51-56.

Sims, J. K., \& Ostman, D. C. (1986). Pufferfish poisoning: emergency diagnosis and management of mild human tetrodotoxication. Annals of emergency medicine, 15(9), 10941098.

Sorokin M. (1973). Puffer fish poisoning . Med J Aust; $1: 957$.

Sui, L. M., Chen, K., Hwang, P. A., \& Hwang, D. F. (2002). Identification of tetrodotoxin in marine gastropods implicated in food poisoning. Journal of natural toxins, 11(3), $213-220$.

Suleiman, M., Muhammad, J., Jelip, J., William, T., \& Chua, T. H. (2017). An outbreak of tetrodotoxin poisoning from consuming horseshoe crabs in Sabah. Southeast Asian Journal of Tropical Medicine and Public Health, 48(1), 197-203.

Sun K., Way J., So P. (1994). Puffer fish poisoning. Anaesth Intensive Care; 22 : 307 - 308. Dati riportati da Lui et al., 2015

Sutherland, A., \& Annual, N. Z. C. O. S. (1985) Letter From Cmas (World Underwater Federation).

Takatani, T., O. Arakawa and T. Noguchi. 2005. Food poisonings due to small gastropods occurring in China. Journal of the Food Hygienic Society of Japan 46: J-208-J-209.

Tambyah, P. A., Hui, K. P., Gopalakrishnakone, P., Chin, N. K., \& Chan, T. B. (1994). Central-nervous-system effects of tetrodotoxin poisoning. The Lancet, 343(8896), 538539.

Tan, T. C. (1980). Puffer fish poisoning. Singapore Fam Physician, 6, 39-40. Dati riportati da Lui et al., 2015

Tibballs, J. (1988). Severe tetrodotoxic fish poisoning. Anaesthesia and intensive care, 16(2), 215-217.

Torda, T. A., Sinclair, E., \& Ulyatt, D. B. (1973). Puffer fish (tetrodotoxin) poisoning. Clinical record and suggested management. Medical Journal of Australia, 599-602.

Trevett, A. J., Mavo, B., \& Warrell, D. A. (1997). Tetrodotoxic poisoning from ingestion of a porcupine fish (Diodon hystrix) in Papua New Guinea: nerve conduction studies. The American journal of tropical medicine and hygiene, 56(1), 30-32.

Tsai, Y. H., Hwang, D. F., Cheng, C. A., Hwang, C. C., \& Deng, J. F. (2006). Determination of tetrodotoxin in human urine and blood using C18 cartridge column, ultrafiltration and LC-MS. Journal of Chromatography B, 832(1), 75-80.

Villa, A. F., Chataigner, D., Arakawa, O., Guegueniat, P., Hommel, D., De, H. L., \& Garnier, R. (2010). Familial tetrodotoxin poisoning in French Guiana. In Clinical Toxicology (Vol. 48, No. 3, Pp. 310-310). 52 Vanderbilt Ave, New York, Ny 10017 Usa: Informa Healthcare.

Viviani R., D’Alessandro F., Manzo L., Crema A., 1978. Le biotossine marine. In : "Problemi igienico-giuridici della produzione e distribuzione delle sostanze alimentari”. Atti deI Convegno, S. Felice Circeo, 4-5-6 giugno.

Wan, C. K., Tsui, S. H., \& Tong, H. K. (2007). A case series of puffer fish poisoning. Hong Kong j. emerg. med, 14, 215-220.

Wang, X. J., Yu, R. C., Luo, X., Zhou, M. J., \& Lin, X. T. (2008). Toxin-screening and identification of bacteria isolated from highly toxic marine gastropod Nassarius semiplicatus. Toxicon, 52(1), 55-61.

Wi, D. H. (2012). A Series of Cases of Fukuda Classification Grade IV Tetrodotoxin Poisoning due to Ingestion of Tetrodotoxin from Puffer Fish. Journal of the Korean Society of Emergency Medicine, 23(1), 154-159.

Wi, D. H. (2013). Transient Diabetes Insipidus Associated with Tetrodotoxin Intoxication: A Case Report. Journal of the Korean Society of Emergency Medicine, 24(2), 230235.

Williams, B. L. (2008). Distribution, ontogenetic profile, and anti-predator efficacy of tetrodotoxin in two species of blue-ringed octopuses (Hapalochlaena lunulata and H. fasciata). University of California, Berkeley.

Wu, Y. J., Cheng, Y. J., Jen, H. C., Pan, C. H., Lin, T. C., Lin, S. J., \& Hwang, D. F. (2011). Liquid chromatography-tandem mass spectrometry determination of the toxicity and identification of fish species in a suspected tetrodotoxin fish poisoning. Journal of food protection, 74(5), 789-795.

Wu, Y. J., Jen, H. C., Deng, J. F., \& Hwang, D. F. (2008). Identification of toxin and species of causative fish roe implicated into a food poisoning incident. 臺灣水產學會刊 , 35(4), 359-367.

Wu, Y. J., Lin, C. L., Chen, C. H., Hsieh, C. H., Jen, H. C., Jian, S. J., \& Hwang, D. F. (2014). Toxin and species identification of toxic octopus implicated into food poisoning in Taiwan. Toxicon, $91,96-102$. 
Yang, C. C., Han, K. C., Lin, T. J., Tsai, W. J., \& Deng, J. F. (1995). An outbreak of tetrodotoxin poisoning following gastropod mollusc consumption. Human \& experimental toxicology, 14(5), 446-450.

Yang, C. C., Liao, S. C., \& Deng, J. F. (1996). Tetrodotoxin poisoning in Taiwan: an analysis of poison center data. Veterinary and human toxicology, $38(4), 282-286$.

Yin, H. L., Lin, H. S., Huang, C. C., Hwang, D. F., Liu, J. S., \& Chen, W. H. (2005). Tetrodotoxication with Nassauris glans: a possibility of tetrodotoxin spreading in marine products near Pratas Island. The American journal of tropical medicine and hygiene, 73(5), 985-990.

Yong, Y. S., Quek, L. S., Lim, E. K., \& Ngo, A. (2013). A case report of puffer fish poisoning in Singapore. Case reports in medicine, 2013.

You, J., Yue, Y., Xing, F., Xia, W., Lai, S., \& Zhang, F. (2015). Tetrodotoxin poisoning caused by Goby fish consumption in southeast China: a retrospective case series analysis. Clinics, $70(1), 24-29$

Zaki; A.M.: 2004, Tetrodoxin poisoning associated with eating puffer fish in Suez City (Egypt). In:1st International Conference on Natural Toxins October 6 University - Egypt 18-19 December 2004.

Zhang, N., Liu, H. X., Su, J., Li, L. F., Ruan, X. Y., \& Wang, X. P. (2007). Nassariids and their toxicity. Chin Fish, 376(3), $72-73$. 
Table 3SM: Toxicity resulting from mouse bioassay (MBA) in fish and gastropods reported in literature.

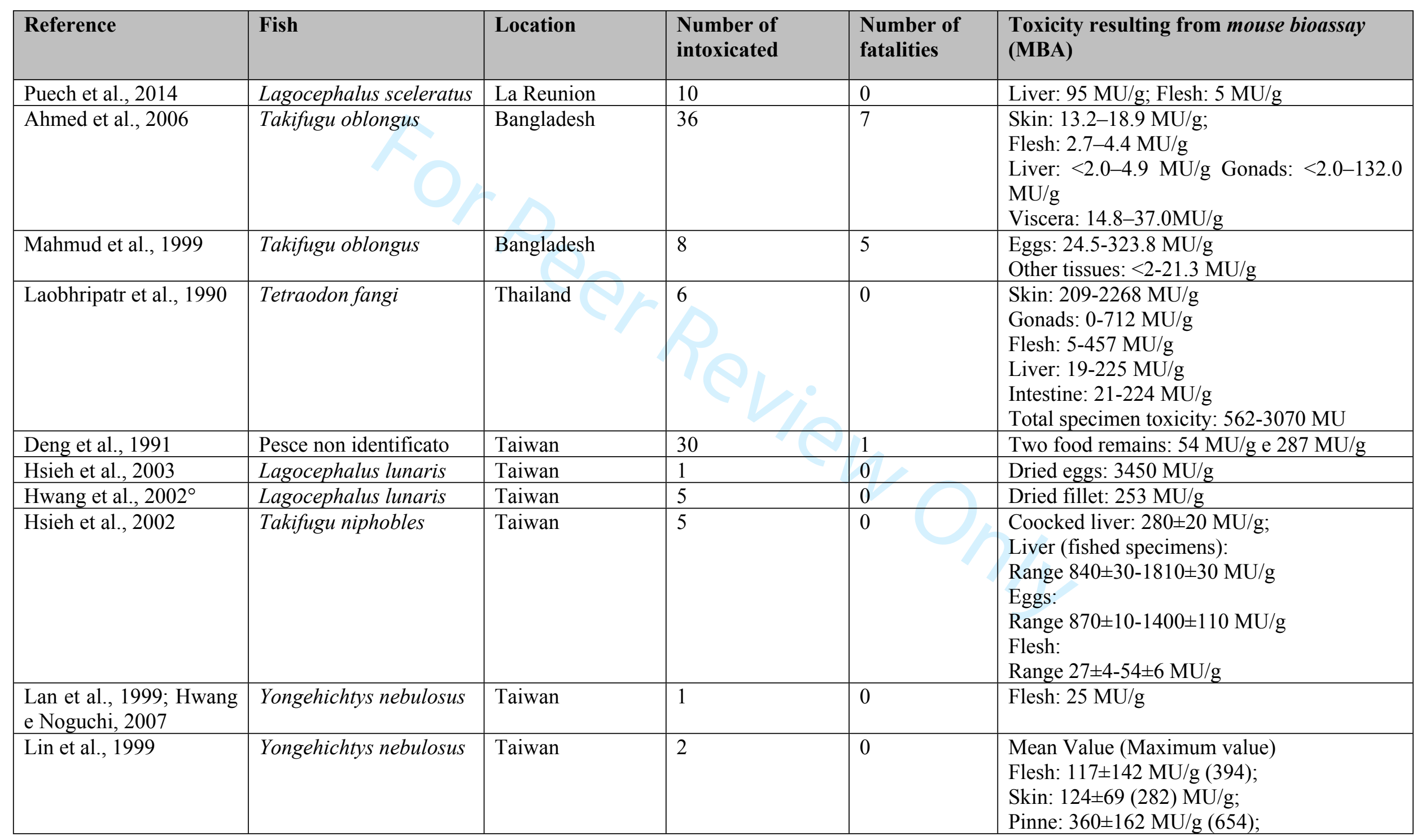




\begin{tabular}{|c|c|c|c|c|c|}
\hline & & & & & $\begin{array}{l}\text { Testa: } 368 \pm 237 \mathrm{MU} / \mathrm{g}(662) ; \\
\text { Viscera: } 285 \pm 170 \mathrm{MU} / \mathrm{g}(624) ; \\
\text { Eggs } 311 \pm 169(510) \mathrm{MU} / \mathrm{g} \text {. } \\
\text { Total toxicity range of specimens: } 5150 \pm 1510 \\
\text { MU }\end{array}$ \\
\hline Yang et al., 1996 & Lagocephalus lunaris & Taiwan & 2 & 1 & Flesh: $120 \mathrm{MU} / \mathrm{g}$ \\
\hline “6 & Lagocephalus lunaris & Taiwan & 2 & 1 & $\begin{array}{l}\text { Eggs: } 1200 \mathrm{MU} / \mathrm{g} \\
\text { Flesh: } 45 \mathrm{MU} / \mathrm{g}\end{array}$ \\
\hline “6 & Generically puffer fish & Taiwan & 2 & 0 & Eggs: $1100 \mathrm{MU} / \mathrm{g}$ \\
\hline “6 & Generically puffer fish & Taiwan & 3 & 1 & Flesh: $150 \mathrm{MU} / \mathrm{g}$ \\
\hline “" & Generically puffer fish & Taiwan & 4 & 0 & Eggs: $150 \mathrm{MU} / \mathrm{g}$ \\
\hline Chen et al., 2010 & Takifugu niphobles & Taiwan & 1 & 0 & Eggs: $300 \mathrm{MU} / \mathrm{g}$ \\
\hline Wu et al., 2008 & Lagocephalus lunaris & Taiwan & 3 & NR & Eggs: $425 \pm 80 \mathrm{MU} / \mathrm{g}$ \\
\hline Hwang et al., $1995^{\circ}$ & Unidentified fish & Taiwan & 2 & 1 & $\begin{array}{l}\text { Flesh } 45 \mathrm{MU} / \\
\text { Skin } 150 \mathrm{MU} / \mathrm{g} \\
\text { Eggs } 1,200 \mathrm{MU} / \mathrm{g}\end{array}$ \\
\hline “6 & Unidentified fish & Taiwan & 5 & 1 & Flesh $120 \mathrm{MU} / \mathrm{g}$ \\
\hline “" & Unidentified fish & Taiwan & 2 & 1 & Eggs: $1100 \mathrm{MU} / \mathrm{g}$ \\
\hline “" & Unidentified fish & Taiwan & 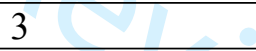 & 1 & Flesh: $150 \mathrm{MU} / \mathrm{g}$ \\
\hline "6 & Unidentified fish & Taiwan & 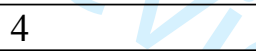 & 0 & Eggs: $150 \mathrm{MU} / \mathrm{g}$ \\
\hline Reference & Gastropod & Location & $\begin{array}{l}\text { Number of } \\
\text { intoxicated }\end{array}$ & $\begin{array}{l}\text { Number of } \\
\text { fatalities }\end{array}$ & $\begin{array}{l}\text { Toxicity resulting from mouse bioassay } \\
\text { (MBA) }\end{array}$ \\
\hline $\begin{array}{l}\text { Fernandez-Ortega et al., } \\
2010 \text {; Rodriguez et al., } \\
2008\end{array}$ & $\begin{array}{l}\text { Charonia lampas } \\
\text { lampas }\end{array}$ & Spain & 1 & 0 & $\begin{array}{l}\text { Digestive gland: } 1432 * \mathrm{MU} / \mathrm{g} \\
\text { Flesh: } 8.48^{*} \mathrm{MU} / \mathrm{g}\end{array}$ \\
\hline Ha e Sato, 2012 & Nassarius spp. & Vietnam & 3 & 2 & Soft tissues: $70 \mathrm{MU} / \mathrm{g}$ \\
\hline “6 & Nassarius spp. & Vietnam & 5 & 0 & $<10 \mathrm{MU} / \mathrm{g}$ TTX and STX \\
\hline “6 & Nassarius spp. & Vietnam & 4 & 1 & $<10 \mathrm{MU} / \mathrm{g}$ TTX and STX \\
\hline Jen et al., 2007 & Nassarius spp. & Taiwan & 1 & 0 & $\begin{array}{l}\text { Flesh: } 645 \mathrm{MU} / \mathrm{g} ; \\
\text { Digestive gland: } 540 \mathrm{MU} / \mathrm{g} \\
\text { TTX and PSP }\end{array}$ \\
\hline Jen et al., 2008 & Niotha clathrata & Taiwan & 3 & 0 & $\begin{array}{l}\text { Digestive gland mean value (maximum } \\
\text { value): } 353.93 \pm 135\left(618^{*}\right) \mathrm{MU} / \mathrm{g} ; \\
\text { Flesh: } 179.77 \pm 89.9\left(393^{*}\right) \mathrm{MU} / \mathrm{g} ; \\
\text { Mean total toxicity of specimens: } \\
202.24 \pm 135^{*} \mathrm{MU} \text {. }\end{array}$ \\
\hline
\end{tabular}




\begin{tabular}{|c|c|c|c|c|c|}
\hline Liu et al., 2004 & $\begin{array}{l}\text { Nassarius papillosus e } \\
\text { Nassarius gruneri }\end{array}$ & Taiwan & 2 & 1 & Two specimens: 320 and $386 \mathrm{MU} / \mathrm{g}$ \\
\hline Hwang et al., 2003 & Olividae & Taiwan & 1 & 0 & $\begin{array}{l}\text { O. miniacea: } 18 \mathrm{MU} / \mathrm{g} \\
\text { O. mustelina: } 10 \mathrm{MU} / \mathrm{g} \\
\text { O. hirasei: } 27 \mathrm{MU} / \mathrm{g}\end{array}$ \\
\hline Hwang et al., 1995b & $\begin{array}{l}\text { Niotha clathrata e } \\
\text { Zeuxis scalaris }\end{array}$ & Taiwan & 26 & NR & $\begin{array}{l}\text { Mean total toxicity of specimens of Niotha } \\
\text { spp.: } 150 \pm 126 \mathrm{MU} \text { e } 345 \pm 192 \mathrm{MU} \text {; } \\
\text { Mean total toxicity of specimens of } Z \text {. } \\
\text { scalaris: } 13 \pm 9 \mathrm{MU} \text { e } 98 \pm 46 \mathrm{MU}\end{array}$ \\
\hline Yang et al., 1995 & $\begin{array}{l}\text { Nassarius conoidalis e } \\
\text { Nassarius castus }\end{array}$ & Taiwan & 17 & 1 & $\begin{array}{l}\text { Mean total toxicity of specimens: } 150 \pm 126 \\
\text { MU in Nassarius conoidalis; } \\
13 \pm 9 \text { MU in Nassarius castus }\end{array}$ \\
\hline $\begin{array}{l}\text { Yin et al., 2005; Hwang } \\
\text { et al., } 2005\end{array}$ & Nassarius glans & Taiwan & 6 & 2 & $\begin{array}{l}\text { Mean value (maximum value) Digestive } \\
\text { gland: } 538 \pm 608 \quad(2048) \quad \mathrm{MU} / \mathrm{g} ; \quad \text { Flesh } \\
1167 \pm 557(2992) \mathrm{MU} / \mathrm{g} \text {. Mean total toxicity } \\
\text { of specimens: } 5188 \pm 1959 \mathrm{MU} \text {. }\end{array}$ \\
\hline Sui et al., 2001 & Zeuxis samiplicutus & China & 31 & 0 & $\begin{array}{l}\text { Digestive gland: } 370 \pm 118(532) \mathrm{MU} / \mathrm{g} \text {; Edible } \\
\text { parts: } 307 \pm 192 \quad(688) \mathrm{MU} / \mathrm{g} \text {. Mean total } \\
\text { toxicity of specimens: } 111 \pm 45 \mathrm{MU} \text {. }\end{array}$ \\
\hline
\end{tabular}




\section{References}

Ahmed, S. (2006). Puffer fish tragedy in Bangladesh: an incident of Takifugu oblongus poisoning in Degholia, Khulna. African Journal of Marine Science, 28(2), 457-

458.

Chen HYH, Juan CHW, Kao TL, Liu CHY. (2010) Central nervous system effects of puffer fish (Tetrodotoxin) poisoning. J Emerg Crit Care Med; $21: 162$ - 166.

Deng, J. F., Tominack, R. L., Chung, H. M., \& Tsai, W. J. (1991). Hypertension as an unusual feature in an outbreak of tetrodotoxin poisoning. Journal of Toxicology: Clinical Toxicology, 29(1), 71-79.

Fernández-Ortega, J. F., Morales-de los Santos, J. M., Herrera-Gutiérrez, M. E., Fernández-Sánchez, V., Loureo, P. R., Rancaño, A. A., \& Téllez-Andrade, A. (2010). Seafood intoxication by tetrodotoxin: First case in Europe. The Journal of emergency medicine, 39(5), 612-617.

Ha, D. V., \& Sato, S. (2012). Toxicity of some marine snails responsible for recent food poisonings in Vietnam. Tạp chí Khoa học và Công nghệ Biển, 10(3), 89-95.

Hsieh, Y. W., Shiu, Y. C., Cheng, C. A., Chen, S. K., \& Hwang, D. F. (2002). Identification of toxin and fish species in cooked fish liver implicated in food poisoning. Journal of food science, 67(3), 948-952.

Hsieh, Y. W., Hwang, P. A., Pan, H. H., Chen, J. B., \& Hwang, D. F. (2003). Identification of tetrodotoxin and fish species in an adulterated dried mullet roe implicated in food poisoning. Journal of food science, $68(1), 142-146$.

Hwang, D.F.; Noguchi T. Tetrodotoxin poisoning. (2007) Adv. Food Nutr. Res., 52, 142-236.

Hwang, D. F., Cheng, C. A., Tsai, Y. H., \& Jeng, S. S. (1995a). Tetrodotoxin associated food poisoning due to unknown fish in Taiwan between 1988-1994. Journal of Pharmaceutical and Biomedical Analysis, 13(9), 165-171.

Hwang, D. F., Cheng, C. A., Tsai, H. T., Shih, D. Y. C., Ko, H. C., Yang, R. Z., \& Jeng, S. S. (1995b). Identification of tetrodotoxin and paralytic shellfish toxins in marine gastropods implicated in food poisoning. Fisheries science, 61(4), 675-679.

Hwang, D. F., Hsieh, Y. W., Shiu, Y. C., Chen, S. K., \& Cheng, C. A. (2002a). Identification of tetrodotoxin and fish species in a dried dressed fish fillet implicated in food poisoning. Journal of food protection, 65(2), 389-392.

Hwang, D. F., Shiu, Y. C., Hwang, P. A., \& Lu, Y. H. (2002b). Tetrodotoxin in gastropods (snails) implicated in food poisoning in northern Taiwan. Journal of food protection, 65(8), 1341-1344.

Hwang, P. A., Tsai, Y. H., Deng, J. F., Cheng, C. A., Ho, P. H., \& Hwang, D. F. (2005). Identification of tetrodotoxin in a marine gastropod (Nassarius glans) responsible for human morbidity and mortality in Taiwan. Journal of food protection, 68(8), 1696-1701.

Hwang, P. A., Tsai, Y. H., Lu, Y. H., \& Hwang, D. F. (2003). Paralytic toxins in three new gastropod (Olividae) species implicated in food poisoning in southern Taiwan. Toxicon, 41(4), 529-533.

Jen, H. C., Lin, S. J., Lin, S. Y., Huang, Y. W., Liao, I. C., Arakawa, O., \& Hwang, D. F. (2007). Occurrence of tetrodotoxin and paralytic shellfish poisons in a gastropod implicated in food poisoning in southern Taiwan. Food additives and contaminants, 24(8), 902-909.

Jen, H. C., Lin, S. J., Tsai, Y. H., Chen, C. H., Lin, Z. C., \& Hwang, D. F. (2008). Tetrodotoxin poisoning evidenced by solid-phase extraction combining with liquid chromatography-tandem mass spectrometry. Journal of Chromatography B, 871(1), 95-100.

128.

Lan, M. Y., Lai, S. L., Chen, S. S., \& Hwang, D. F. (1999). Tetrodotoxin intoxication in a uraemic patient. Journal of Neurology, Neurosurgery \& Psychiatry, 67(1), 127-

Laobhripatr, S., Limpakarnjanarat, K., Sangwonloy, O., Sudhasaneya, S., Anuchatvorakul, B., Leelasitorn, S., \& Saitanu, K. (1990). Food poisoning due to consumption of the freshwater puffer Tetraodon fangi in Thailand. Toxicon, 28(11), 1372-1375.

Lin, S. J., et al. (1999) Acute goby poisoning in southern Taiwan. Journal of natural toxins 8.1 141-147.

Lin, C. L., Hsieh, C. H., Hsieh, Y. L., Tai, Y. C., \& Hwang, D. F. (2013). Application of LC-MS/MS in identification of toxin in the causative gastropod and victim samples. Journal of Marine Science and Technology, 21, 52-57.

Liu, F. M., Fu, Y. M., \& Shih, D. Y. C. (2004). Occurrence of tetrodotoxin poisoning in Nassarius papillosus Alectrion and Nassarius gruneri Niotha. Journal of Food and Drug Analysis, 12(2), 189-192. 
Mahmud, Y., Tanu, M. B., \& Noguch, T. (1999). First occurrence of a food poisoning incident due to ingestion of Takifugu oblongus, along with a toxicological report on three marine puffer species in Bangladesh. Food Hygiene and Safety Science (Shokuhin Eiseigaku Zasshi), 40(6), 473-480.

Puech, B., Batsalle, B., Roget, P., Turquet, J., Quod, J. P., Allyn, J., ... \& Vandroux, D. (2014). Family tetrodotoxin poisoning in Reunion Island (Southwest Indian Ocean) following the consumption of Lagocephalus sceleratus (Pufferfish). Bull. Soc. Pathol. Exot, 107, 79-84.

Rodriguez, P., Alfonso, A., Vale, C., Alfonso, C., Vale, P., Tellez, A., \& Botana, L. M. (2008). First toxicity report of tetrodotoxin and 5, 6, 11 -trideoxyTTX in the trumpet shell Charonia lampas lampas in Europe. Analytical chemistry, 80(14), 5622-5629.

Sui, L. M., Chen, K., Hwang, P. A., \& Hwang, D. F. (2002). Identification of tetrodotoxin in marine gastropods implicated in food poisoning. Journal of natural toxins, 11(3), 213-220.

Wu, Y. J., Jen, H. C., Deng, J. F., \& Hwang, D. F. (2008). Identification of toxin and species of causative fish roe implicated into a food poisoning incident. 臺灣水產學 會刊, 35(4), 359-367.

Yang, C. C., Han, K. C., Lin, T. J., Tsai, W. J., \& Deng, J. F. (1995). An outbreak of tetrodotoxin poisoning following gastropod mollusc consumption. Human \& experimental toxicology, 14(5), 446-450.

Yang, C. C., Liao, S. C., \& Deng, J. F. (1996). Tetrodotoxin poisoning in Taiwan: an analysis of poison center data. Veterinary and human toxicology, 38(4), $282-286$.

Yin, H. L., Lin, H. S., Huang, C. C., Hwang, D. F., Liu, J. S., \& Chen, W. H. (2005). Tetrodotoxication with Nassauris glans: a possibility of tetrodotoxin spreading in marine products near Pratas Island. The American journal of tropical medicine and hygiene, 73(5), 985-990. 